EDUARDO HENRIK AUBERT

\title{
A IMPUGNAÇÃO ESPECIFICADA DOS FATOS NO PROCESSO CIVIL BRASILEIRO
}

\author{
Tese de Doutorado
}

Orientador: Professor Associado Dr. Heitor Vitor Mendonça Sica

UNIVERSIDADE DE SÃO PAULO

FACULDADE DE DIREITO

São Paulo - SP

2019 



\section{EDUARDO HENRIK AUBERT}

\section{A impugnação especificada dos fatos no processo civil brasileiro}

Tese apresentada a Banca Examinadora do Programa de Pós-Graduação em Direito, da Faculdade de Direito da Universidade de São Paulo, como exigência parcial para obtenção do título de Doutor em Direito, na área de concentração de Direito Processual, sob a orientação do Professor Associado Dr. Heitor Vitor Mendonça Sica.

\section{UNIVERSIDADE DE SÃO PAULO}

FACULDADE DE DIREITO

São Paulo - SP 

Nome: AUBERT, Eduardo Henrik.

Título: A impugnação especificada dos fatos no processo civil brasileiro.

Local de aprovação:

Data de aprovação:

\section{BANCA EXAMINADORA}

Prof.(a). Dr.(a)

\section{Instituição:}

Julgamento:

Prof.(a). Dr.(a)

Instituição:

Julgamento:

Prof.(a). Dr.(a)

Instituição:

Julgamento:

Prof.(a). Dr.(a)

Instituição:

Julgamento:

Prof.(a). Dr.(a)

Instituição:

Julgamento: 



\section{AGRADECIMENTOS}

Aos meus mestres, ego nanus gigantum humeris insidens, na pessoa do meu orientador, Heitor Vitor Mendonça Sica, ille gigas me humeris ferens, pela atenção, pelo cuidado, pelo contínuo estímulo, pelo exemplo.

Aos meus colegas da Faculdade de Direito do Largo de São Francisco, flores inter spinas, pela memória de uma presença em lugar que se cristalizou, sicut sol in conspectu meo, et sicut luna perfecta.

À minha família, a que resta, quia exstat, a que falta, quia fuit. 

O desenvolvimento do diálogo (eu quase diria sua vegetação) chama atenção para o conceito de resposta. Também a esse propósito, quem tem amor pelas palavras se pergunta o que tenha a ver com o modo comum de considerar a resposta o elemento da fides, ao qual se liga o significado originário de sponsio e de spondeo (responsio, de re-spondere). (...) A bem examinar, toda interrogação se termina com a fórmula romana: spondesne?, mesmo se ela está apenas subentendida. Quem interroga, mais ou menos, confia (Francesco CARNELUTTI. Diritto e Processo. Napoli: Morano, 1958, § 112, p. 184). 



\title{
RESUMO
}

Este trabalho consiste em uma investigação de natureza dogmática sobre a impugnação especificada dos fatos no processo civil brasileiro, voltada particularmente a reconstruir sistematicamente o conteúdo normativo do art. 341 do CPC/2015 e, com isso, apresentar o seu regime jurídico. Pretende-se, com esse esforço, apresentar critérios que permitam determinar, em uma variedade de situações, se houve impugnação especificada dos fatos articulados na petição inicial. Para tanto, examinam-se, sucessivamente: (1) a natureza jurídica da impugnação especificada dos fatos; (2) sua localização em um sistema axiológico; (3) seus objeto e conteúdo mínimo; enfim (4) suas relações com outros componentes do sistema processual civil.

Palavras-chave: impugnação especificada dos fatos, posições jurídicas, sistema jurídico processual

\begin{abstract}
This research is an investigation of the duty to challenge the facts in a specified manner in Brazilian procedural law from the perspective of legal dogmatics. It aims at reconstructing systematically the normative content of article 341 of the Brazilian Code of Civil Procedure and sketching its legal regime. The underlying concern is developing sound criteria to determine, in a wide range of situations, whether the facts put forward in the complaint were actually challenged in a specified manner in the defense. To this purpose, the following issues are approached successively: (1) the legal nature of the duty to challenge the facts in a specified manner; (2) its position in an axiological system; (3) its object and its minimum content; finally (4) its relations with other components of the Brazilian procedural system.
\end{abstract}

Keywords: duty to challenge the facts in a specified manner, jural relations, procedural legal system 



\section{NOTA SOBRE TRADUÇÕES E REFERÊNCIAS}

A menos que haja indicação expressa, todas as traduções são de nossa autoria. Via de regra, os originais não vêm transcritos, para evitar uma sobrecarga de notas de rodapé. As duas exceções a essa regra são os textos em língua antiga (grego e latim) e textos em língua estrangeira que são objeto de uma análise mais detida, para a qual é relevante (e muita vez discutida no texto) a seleção lexical.

As referências constantes nas notas de rodapé podem ser todas encontradas na bibliografia. Apenas a primeira referência a uma obra em cada capítulo é completa, abreviando-se na sequência, mas com elementos suficientes para permitir sua localização diretamente na bibliografia. 



\section{NOTA SOBRE SIGLAS E ABREVIATURAS}

As siglas e abreviaturas empregadas nesta tese são todas correntes, pelo que descaberia uma listagem específica. Trata-se dos nomes dos tribunais superiores (STF, STJ...), dos nomes de códigos e de outros textos normativos (CPC, CC, CF...).

Ademais desses casos de amplíssima difusão e plena inteligibilidade, não nos valemos de siglas ou de abreviaturas específicas, com exceção apenas dos seguintes casos:

ADP-39: Alexandre de PAULA. O Processo Civil à Luz da Jurisprudência. Rio de Janeiro: Forense, 1940ss. 35 v..

O primeiro número após a sigla indica o volume, separado por vírgula da página e, então, por barra oblíqua, do número de entrada da decisão no conjunto da recolha.

RT: $\quad$ Revista dos Tribunais.

O primeiro número, separado por barra oblíqua, indica o volume correspondente, e o número sucessivo, separado por vírgula, as páginas em questão. 



\section{SUMÁRIO}

CAPÍTULO 1. Natureza jurídica da impugnação especificada dos fatos. p. 9

1. Considerações introdutórias: posições jurídicas e o CPC/2015. p. 9

2. O ônus é posição jurídica ou é mero interesse?.

2.1. Ônus como tutela do próprio interesse em CARnElutTI, BeTti e GOLDSCHMIDT

2.2. O ônus como imperativo hipotético.

2.3. A necessária autonomia das categorias das posições jurídicas.

3. A natureza jurídica da impugnação especificada dos fatos.

3.1. Um modelo sistemático para a descrição das posições jurídicas: a contribuição de WESLEY NEWCOMB HOHFELD

3.2. A dinâmica das posições jurídicas na relação jurídica processual: um esboço

3.3. O dever de impugnação especificada dos fatos

CAPÍTULO 2. Impugnação especificada dos fatos e sistema axiológico: a juridicização da retórica.

4. Considerações introdutórias: uma tensão persistente.

5. Embate entre valor verdade e valor liberdade no nascimento da retórica.

6. O predomínio do valor liberdade e a tradição retórica clássica. 
6.2. A retórica clássica romana.............................................................. p. 80

7. A nova axiologia do valor verdade e o processo romano-canônico................. p. 91

7.1. Publicização do processo e cristianização da retórica............................. p. 91

7.2. Uma referência: a Summa de ordine iudiciario, de Gratia Aretino (após 1237).

p. 97

7.3. O dever de responder com clareza no processo romano-canônico......... p. p. 103

8. O ius proprium, com especial atenção para o processo português................... p. 111

8.1. Dos forais à legislação de Afonso III..................................................... p. p. 115

8.2. As Ordenações do Reino.................................................................... p. 122

9. O Brasil entre a tradição retórica e os caminhos da modernidade.................... p. 137

9.1. Brasil imperial............................................................................. p. 141

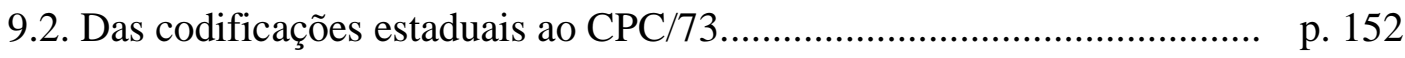

CAPÍTULO 3. Estrutura da impugnação especificada dos fatos: objeto e conteúdo.

p. 177

10. Considerações introdutórias: alegação de fato e proposição.......................... p. 177

11. Os fatos e a figura do fato...................................................................... p. 183

11.1. A figura do fato............................................................................ p. 191

11.2. Os fatos impeditivos: breve aceno a um construto doutrinário.............. p. 203

11.3. A linha divisória entre fatos jurídicos e fatos simples......................... p. 208

11.4. Causa de pedir, pré-compreensão e reenquadramento dos fatos.......... p. 218

12. Os fatos e o réu como sujeito cognoscente.................................................. p. 229

12.1. Fatos e atos jurídicos........................................................................ p. 236

12.2. Fatos que são suporte de existência, validade e eficácia...................... p. 252

13. Os fatos em sua relação recíproca................................................................ p. p. 266

14. Conclusão parcial: regime geral da impugnação especificada dos fatos....... p. 272

CAPÍTULO 4. Impugnação especificada dos fatos no sistema do processo civil brasileiro.

p. 275

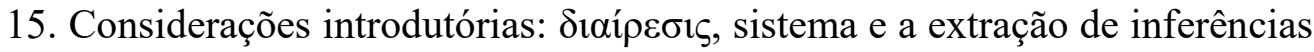
normativas

p. 276

16. Impugnação especificada e contraditório...................................................... p. 283

17. Impugnação especificada e fase postulatória................................................ p. 287

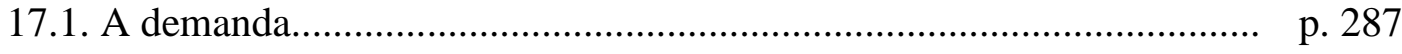

17.1.1. O pedido: CPC/2015, arts. 322; 324; 330............................. p. 287

17.1.2. Estabilização da demanda: CPC/2015, arts. 329; 357, $\S \S 2^{\circ}$ e $3^{\circ} . \quad$ p. 299 
17.2. A resposta do réu.......................................................................... p. 307

17.2.1. Contestação: CPC/2015, arts. 336; 436; 437............................. p. 307

17.2.2. Ausência de contestação: CPC/2015, arts. 344; 345; 348; 349 ..

p. 312

17.3. Probidade e abuso de direito processual: CPC/2015, arts. 77 e $80 \ldots \ldots \ldots$ p. 325

18. Impugnação especificada e fase probatória.................................................. p. 334

18.1. Considerações preliminares sobre o "ônus" da prova: CPC/2015, art. 373.

p. 335

18.2. Depoimento pessoal: CPC/2015, arts. 386; 388; 392 ....................... p. 345

18.3. Confissão: CPC/2015, arts. 389; 393; 395 .................................... p. 349

19. Impugnação especificada e fase decisória: $\mathrm{CPC} / 2015$, art. 489 , § $1^{\circ}$.

p. 355

20. Impugnação especificada e fase recursal: CPC/2015, arts. 932, III; 1.021, $\S \S 1^{\circ}$ a $3^{\circ}$

p. 362

21. Impugnação especificada e fase executiva: CPC/2015, arts. 525; 917.

p. 369

22. Impugnação especificada e procedimentos especiais.

p. 376

22.1. Da utilidade do estudo dos procedimentos especiais: relações associativas.

p. 380

22.2. Ação de consignação em pagamento: CPC/2015, art.

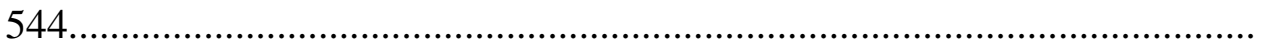

p. 384

22.3. Ação de exigir contas: $\mathrm{CPC} / 2015$, arts. $550, \S \S 1^{\circ}$ e $3^{\circ}$, e 551 , caput e $\S 1^{\circ}$ p. 391

22.4. Inventário: $\mathrm{CPC} / 2015$, art. 627

p. 395

22.5. Embargos de terceiro: CPC/2015, art. 680.

p. 399

22.6. Ação monitória: $\mathrm{CPC} / 2015$, art. $702, \S \S 1^{\circ}$ a $3^{\circ}$.

p. 401

22.7. Homologação do penhor legal: CPC/2015, art. 704.

p. 402

CONCLUSÃO.

p. 405

BIBLIOGRAFIA

p. 413 



\section{INTRODUÇÃO}

O tema desta investigação localiza-se em um plano rente ao dia-a-dia-forense. Vejam-se dois exemplos.

Uma senhora ajuizou demanda com o fim de ver declarada a inexigibilidade de dívida que lhe era cobrada por clínica veterinária. ${ }^{1}$ Cadela de sua propriedade fora submetida a cirurgia de emergência, mas o valor da cobrança excedia largamente, em mais de três vezes, o orçamento com o qual havia anuído. Após examinar a planilha em que a clínica discriminava os custos dos insumos da cirurgia e da internação, entendeu ter havido sobrepreço de diversos itens, duplicidade de cobranças, entre outras distorções, pelo que concluiu, diante da resistência da clínica a rever o valor pretendido, pela necessidade de se dirigir ao Judiciário. Na petição inicial, apontou as inconsistências da planilha separadamente, fundamentando sua discordância em pesquisa de preços junto a outras três clínicas da região.

Ocorre que, em sede de contestação, no mérito, a clínica se limitou à lacônica afirmação a seguir transcrita: "os preços praticados pelo Réu estão em total consonância com a prática dos preços do mercado". Há dúvida relevante a respeito de uma afirmação dessa natureza ter bastado para impugnar os fatos apresentados pela autora, já que, na inicial, havia discriminação e fundamentação de valor por valor, ao passo que a contestação se limitou na verdade a inverter a conclusão geral da autora, segundo a qual os preços eram muito superiores à média do mercado, vale dizer, resolvia-se a contestação na negativa daquela proposição: “os preços praticados pelo Réu não são superiores à média do mercado".

O segundo caso, apesar de bastante mais dramático, levanta problema semelhante. Uma senhora idosa havia sido submetida a cinco cirurgias de coluna no Hospital do Servidor Público de São Paulo, e, na sequência, a outras duas com médico particular para buscar corrigir os danos advindos das cinco primeiras. ${ }^{2}$ Os prontuários sugeriam gravíssimo erro médico, já que, quando da primeira cirurgia, não fora investigada - apesar

\footnotetext{
${ }^{1}$ Autos do processo no 0001699-46.2016.8.26.0299.

${ }^{2}$ Autos do processo $n^{\circ} 1016130-30.2016 .8 .26 .0053$.
} 
de ter sido aventada nos prontuários - a hipótese de a cliente ser portadora de osteoporose, condição clínica que teria demandado uma conduta radicalmente distinta por parte dos médicos, atentos à dificuldade de fixação de pinos metálicos.

Descritos os fatos em pormenor na inicial, com cerca de 300 páginas de documentação discutidas pormenorizadamente, a Procuradoria que se ocupou da defesa se limitou a levantar pontos de direito e, relativamente aos fatos narrados com minudência na inicial, restringiu-se a asseverar o seguinte:

Embora presente o dano, é fato que todos os exames e tratamentos necessários a fim de diagnosticar e tratar a paciente foram realizados, conforme se infere da leitura dos prontuários médicos juntados. Ora, ao contrário do alegado, o hospital público sempre agiu de forma atender [sic] a paciente, acompanhar seu quadro clínico, sendo que foram realizados os procedimentos corretos, feito exames [sic] e procedimentos cirúrgicos.

Também aqui resta bastante duvidoso ter havido impugnação especificada dos fatos narrados, pela generalidade do discurso, sem aderência às alegações particulares formuladas em torno do caso.

Diante da dúvida razoável sobre ter ou não havido impugnação especificada dos fatos, como se deve guiar o operador do direito, seja o próprio réu para evitar oferecer contestação que não produza os efeitos pretendidos, seja o autor para averiguar, em réplica, o atendimento ou não ao mandamento de impugnação especificada, seja, enfim, o juiz, para conduzir o processo às suas fases ulteriores, direcionando a atividade probatória ou julgando antecipadamente o mérito?

A despeito da frequência com que situações como essas se apresentam no foro, inexiste, a nosso saber, investigação em nosso direito que se debruce especificamente sobre o tema da impugnação especificada dos fatos, disciplinada algo laconicamente no art. 341 do CPC/2015. Nas condições atuais, sem critérios claros, a previsão de uma impugnação especificada dos fatos acaba por quedar letra morta ou mesmo se configurar em fonte de insegurança jurídica. É justamente essa lacuna científica, que se nos afigura como relevante, por diversas razões que ficarão claras no decorrer do trabalho, que o presente trabalho pretende preencher. 
É corrente no foro que se despache "à réplica” sem ponderação da existência e/ou da natureza da controvérsia e que se abra então a instrução probatória de forma pouco refletida. Ao fim e ao cabo, de acordo com o código processual da vida real, há largo espaço ainda para contestações que pouco se distinguem da negativa geral, que o legislador busca coibir, sem grande sucesso, ao que parece, desde o CPC/1939. Daí a advertência de MANOEL ANTONIO TEIXEIRA FILHO, em forma de:

sugestão aos juízes: para que o ônus da impugnação específica alcance os efeitos práticos desejados pelo legislador, é indispensável que o magistrado, antes de realizar a instrução oral do processo, ou de deferir a produção de provas requeridas pelas partes, examine, com atenção, se o fato foi, efetivamente, contestado. (...) Sem esse conhecimento amplo e seguro dos articulados e de tudo o mais que dos autos conste, o juiz será um mau condutor do processo e, em consequência, um frustrador dos objetivos das normas legais devotadas à racionalização e à celeridade do procedimento. ${ }^{3}$

Em consonância com as preocupações acima externadas, este trabalho tem por objetivo principal proceder a uma investigação de natureza dogmática sobre a impugnação especificada dos fatos no processo civil brasileiro, voltada particularmente a reconstruir sistematicamente o conteúdo normativo do art. 341 do CPC/2015. Pretendese, com esse esforço, apresentar critérios que permitam determinar, em uma variedade de situações, se houve impugnação especificada dos fatos articulados na petição inicial. Esclarecemos na sequência os termos desse enunciado.

Entende-se aqui reconstruir em sentido próprio, já que construir é "collocar a frase, traduzir segundo a construcção natural". ${ }^{4}$ Isto é, trata-se de trabalho de interpretação que objetiva não a mera paráfrase do texto legal, mas antes a desconstrução (análise,

\footnotetext{
${ }^{3}$ M. A. TEIXEIRA FILHO. Petição inicial e resposta do réu. São Paulo: LTr, 1996, p. 299. Em sentido semelhante, entendendo que "o ônus da impugnação específica é uma importante ferramenta que pode e deve ser aproveitada pelos operadores do direto", na "árdua tarefa de agilizar a prestação jurisdicional", cf. A. de P. MESQUITA. Ônus da impugnação específica é ferramenta importante. Conjur, 11 mai. 2006. Disponível em:

< https://www.conjur.com.br/2006-mai-11/onus_impugnacao_especifica_ferramenta_importante> Acesso em: 20 set. 2018.

${ }^{4}$ A. de MORAES SILVA. Diccionario da Lingua Portugueza: tomo primeiro. Lisboa: Typographia Lacerdina, 1813, p. 454.
} 
separação) da previsão do texto normativo e sua síntese sistemática (reconstrução), de modo a especificar e detalhar o conteúdo da impugnação especificada dos fatos à luz do sistema. Assim, não basta dizer que "o réu deverá manifestar-se de modo preciso e rigoroso sobre os fatos mencionados na petição inicial... uma resposta específica e precisa". 5 Tampouco esclarece suficientemente a afirmação de que o réu "deverá contestar (impugnar) item por item da peça inicial, dando as razões da sua impugnação e os motivos porque não são verdadeiras as impugnações do autor na peça inicial". ${ }^{6}$

É preciso, antes, em um círculo hermenêutico ${ }^{7}$ que envolve uma pluralidade de hipóteses fáticas sobre as quais potencialmente incide a norma jurídica - muitas das quais prefiguradas em outros pontos do ordenamento como situações juridicamente típicas -, depurar as formas pelas quais se realiza a adequação entre fato e norma. Como demonstram ordenamentos jurídicos assemelhados, neste ponto, ao brasileiro, eventualmente alguns desses casos se tornam tão relevantes a ponto de suscitar uma formulação legislativa especificadora, como no caso da declaração de desconhecimento de fato "pessoal ou de que o réu deva ter conhecimento", que o art. 574, 4, do CPC português de 2013, sob inspiração do $\S 138$, 4, da ZPO alemã, equipara à ausência de impugnação (tomada de "posição definida"). É tarefa da pesquisa, em área tão abrangente quanto possível, identificar e explicar, de modo sistemático - já que é o sistema que permite que se encontrem as normas para os casos concretos que não foram pontualmente

\footnotetext{
${ }^{5}$ P. FERREIRA. Da resposta do réu. 2.ed. São Paulo: Saraiva, 1987, p. 34.

${ }^{6}$ A. de OLIVEIRA. A contestação do réu no processo ordinário: defesas diretas e indiretas contra o processo e sua área de circunfluência. São Paulo: Julex, 1988, p. 29. Poderíamos continuar a listar literatura que não faz mais que parafrasear o texto legal: "Deverá, pois, o réu, manifestar-se precisamente sobre os fatos narrados na petição inicial...” (J. R. PARIZATTO. Da contestação e da revelia: doutrina, jurisprudência, prática forense. Rio de Janeiro: Aide, 1991, p. 76.) "É o que a doutrina chama de princípio do ônus da impugnação específica, isto é, o réu deve impugnar um a um os fatos articulados pelo autor..." (G. C. de ARAÚJO JÚNIOR. A resposta do réu no processo civil: teoria e prática. Rio de Janeiro: Forense, 1999, p. 10.) Não é toda a literatura que assim procede, no entanto, tendo essa exemplificação o propósito de assinalar o espectro menos elaborado da produção bibliográfica sobre o assunto.

${ }^{7} \mathrm{Na}$ lição de GADAMER, "[a] regra hermenêutica segundo a qual devemos compreender o todo a partir do individual e o individual a partir do todo se origina na antiga retórica e foi adotada pela hermenêutica moderna, passando da arte de falar para a arte de compreender. Há em ambos os casos uma relação circular". (H.-G. GADAMER. On the Circle of Understanding. In: John M. CONNOLY; Thomas KEUTNER; HansGeorg GADAMER (org.). Hermeneutics versus science? Three German views. Notre Dame: University of Notre Dame Press, 1988, p. 68-78, aqui p. 68.)
} 
aludidos no texto positivado ${ }^{8}$-, o âmbito de incidência da norma. ${ }^{9}$ Tal é a ideia de reconstrução.

A pesquisa é de natureza dogmática. ${ }^{10}$ Por essa caracterização se entende um tipo de tratamento dos enunciados normativos que visa a promover um adensamento do conhecimento deontológico sobre o direito por meio de inferências lógicas sistematicamente ordenadas. A noção de dogmática de que aqui nos achegamos pode ser convenientemente captada na seguinte formulação de HANS DÖLLE:

Ele [o conceito de dogmática] é... empregado quando... o labor do conhecimento jurídico não se reduz à apreciação do psicológico, do social e do sociológico, mas é direcionado à obtenção (Gewinnung) de uma norma jurídica por meio do esclarecimento (Aufhellung) de determinados complexos de sentido jurídicos (juristischer Sinnzusammenhänge), de tal modo sobretudo que o resultado encontrado possa ser submetido, na mais ampla extensão possível, a uma verificação racional, ou lógico-formal. ${ }^{11}$

\footnotetext{
${ }^{8}$ É todo o sentido da invectiva de DWORKIN contra a ideia de discricionariedade judicial. Cf. R. DWORKIN. The Model of Rules I. In: IDEM. Taking Rights Seriously. Cambridge: Harvard University Press, 1978, p. 14-45, especialmente p. 31-39.

${ }^{9}$ No limite, trata-se de considerar a defesa de mérito direta no processo civil brasileiro como potencial "negação motivada". A expressão é de GiAN ANTONIO Micheli (La carga de la prueba. Bogotá: Temis, 1989, p. 356), mas empregada para o caso em que o réu apresenta consequências jurídicas distintas para o fato alegado para o autor, isto é, nega a consequência, e não o fato. Mas, ressignificando a expressão, parece-nos que ela pode ser adequadamente usada para explicitar que impugnar especifica(da)mente é negar com algum conteúdo. A natureza desse conteúdo - se e quando ele pode ser caracterizado como motivação e fundamentação, termos consagrados por nosso ordenamento para se referir à decisão judicial - será investigada por esta pesquisa, guardando em mente assim a amplitude possível de concretização do dispositivo legal.

${ }^{10}$ Não podemos aqui nos estender sobre a (aparente) aporia da expressão "pesquisa dogmática", que, para alguns, soa como oxímoro. Baste dizer que a dogmática moderna compartilha do mesmo movimento de radical transformação do conhecimento que, no bojo da filosofia iluminista, também produziu os códigos modernos. Trata-se de uma redução do horizonte de cognoscibilidade e de uma intensificação da cognoscibilidade no interior desse horizonte. Segundo CASSIRER, "[a] potência da razão humana não está em romper os limites do mundo da experiência a fim de encontrar um caminho de saída para o domínio da transcendência, mas em ensinar-nos a percorrer esse domínio empírico com toda a segurança e a habilitálo comodamente". (E. CASSIRER. A filosofia do Iluminismo. Campinas: UNICAMP, 1997, p. 31-32.)

${ }^{11}$ H. DÖLLE, Rechtsdogmatik und Rechtsvergleichung, Rabels Zeitschrift für ausländisches und internationales Privatrecht, n. 34, 3/4, p. 403-410, 1970, aqui p. 404. Esse conceito é reformulado por Bydlinski, com base em Dölle, nos seguintes termos: "a dogmática jurídica é o labor do conhecimento jurídico, destinado à obtenção de uma norma jurídica, com base comprovável o mais racional possível" (F. BYDLINSKI, Unentbehrlichkeit und Grenzen methodischen Rechtdenkens. Archiv für die civilistische Praxis, n. 188 (5), p. 447-488, 1988, aqui p. 477).
} 
Nessa formulação, parece-nos desde logo relevante destacar o cerne cognitivo da dogmática jurídica ( (Aufhellung) a respeito do sistema jurídico (juristischer Sinnzusammenhänge) extremado, como objetividade ideal, de contingências subjetivas, tanto individuais (“psicológico") como coletivas (“sociológico") - e a respeito das normas que o compõem, que dele se extraem (Gewinnung) por meio de procedimentos racionais e verificáveis.

Para abreviar uma discussão que se poderia estender indefinidamente, dado seu caráter zetético, na categoria viehwegiana entre nós disseminada por SAMPAIO FERRAZ JR., pode-se adotar, como aceno para o terreno em que se desenvolverá a pesquisa, já que se trata de tomar por base o ordenamento posto como limite especulativo, mas dentro dele desenvolver um intenso processo de conhecimento, a definição de LARENZ, em tudo e por tudo compatível com a definição de DöLlE, com quem compartilha a ideia da dogmática como processo racional de conhecimento do dado jurídico. Para LARENZ, "dogmática" pode designar "uma atividade que consiste na desenvolução de conceitos determinados pelo conteúdo, no preenchimento adicional de princípios e na recondução de normas e de complexos normativos a estes conceitos fundamentais e a princípios." 12

Tal, em breves termos, a tarefa a que nos propomos, na esperança de descrever o regime jurídico da impugnação especificada no processo civil brasileiro e, com isso, permitir que momento particularmente importante para o desenrolar da marcha processual possa ser abordado, pelos operadores do direito, de forma o mais segura possível.

Este trabalho está organizado em quatro capítulos.

O capítulo 1 ("Natureza jurídica da impugnação especificada dos fatos") visa a oferecer um enquadramento para discutir a questão central de saber se a impugnação especificada dos fatos no processo civil brasileiro é ônus ou dever. Partimos da distinção kantiana entre imperativos hipotéticos e imperativos categóricos para fundamentar o que são posições especificamente jurídicas e, na sequência, valemo-nos de modelo proposto por WeSLEY NEWCOMB HoHFELD com que se pode desenvolver espécie de "gramática mínima" das posições jurídicas. Esse modelo, tomado como válido do ponto de vista da

\footnotetext{
${ }^{12}$ K. LARENZ. Metodologia da ciência do direito. 6.ed.. Lisboa: Calouste Gulbenkian, 2012, p. 319.
} 
teoria geral do direito, é, então, discutido à luz das posições jurídicas processuais, para que enfim se possa responder à questão central do capítulo.

O capítulo 2 ("Impugnação especificada dos fatos e sistema axiológico: a juridicização da retórica") parte da constatação de que a forma dos atos processuais, e mais especificamente dos atos postulatórios, foi desenvolvida em longo processo de juridicização da retórica judiciária, em que o potencial de imperatividade da forma dos atos processuais ora se impôs mais fortemente, ora deixou larga parcela do regramento das condutas ao alvitre das partes. Essas evoluções foram condicionadas por mais profundas alterações na valoração da função do processo judicial e do sistema jurídico, mais amplamente. Por meio de uma investigação da reelaboração contínua desse sistema axiológico, indiciada pelo tratamento da impugnação especificada no direito ocidental entre a Roma clássica e o Brasil contemporâneo, com as limitações devidamente explicadas no curso do texto, trata-se de compreender a axiologia que sustenta a conformação da impugnação especificada dos fatos em nosso sistema jurídico atual.

O capítulo 3 (“A estrutura da impugnação especificada dos fatos: objeto e conteúdo") ataca diretamente o problema de saber sobre quais alegações de fato incide o mandamento da impugnação especificada e, mais que isso, qual o conteúdo desse mandamento quando ele incide. Para tanto, investiga o problema das alegações de fato no processo, explorando as categorizações do fato que têm relevância para o delineamento do regime jurídico da impugnação especificada, vista a própria categorização como critério lógico necessário para a compreensão do regime.

O capítulo 4 ("Impugnação especificada dos fatos no sistema do processo civil brasileiro"), enfim, realiza um esforço hermenêutico concentrado, visando a um adensamento das conclusões do capítulo 3, relativamente ao modo de incidência do mandamento de impugnação especificada. Para tanto, examina uma série de dispositivos correlatos ao art. 341 no CPC/2015 e pondera, a cada ponto, de que modo se deve entender a correlação, se índice de uma norma mais geral, que portanto deve incidir também sobre a impugnação especificada, compondo o seu regime jurídico, ou se marca da especificidade de um regramento outro que, portanto, só indica o regime jurídico da impugnação especificada dos fatos pela contraposição, vale dizer por sua não-incidência.

Os capítulos 1 e 2 assumem, no conjunto da investigação, função de assentar premissas teóricas sem as quais o trabalho propriamente dogmático, desenvolvido de 
forma mais direta nos capítulos 3 e 4, quedaria sobremaneira dificultado e, segundo pensamos, carregaria equívocos que precisam ser desfeitos para a perfeita compreensão da matéria. A pesquisa empreendida nesses capítulos resulta, mais particularmente, na obtenção de duas premissas, instrumentais para o raciocínio subsequente: a definição da natureza jurídica da impugnação especificada (item 3.3) e a identificação do conteúdo axiológico da impugnação especificada no processo civil brasileiro (item 9.2).

Na segunda metade do trabalho, em que buscamos reconstruir mais diretamente o regime jurídico da impugnação especificada dos fatos, os resultados parciais são paulatinamente sumulados em enunciados que têm por objetivo dar a ver as inferências normativas que vão sendo produzidas no decorrer da pesquisa. Na conclusão do capítulo 3 (item 14) e na conclusão geral do trabalho, essas inferências, assim sumuladas pari passu com o trabalho analítico, são apresentadas de forma ordenada.

Com isso, não há a pretensão de que teremos chegado à definição completa e definitiva do regime jurídico da impugnação especificada dos fatos no processo civil brasileiro, até mesmo porque o trabalho dogmático é continuamente passível de adensamento pela aplicação de métodos racionais ao variegado material que se apresenta à intelecção do jurista.

Parece-nos, no entanto, que se atinge uma primeira apreensão ordenada da matéria a partir da qual, pensamos, problemas como os postos no princípio desta introdução podem ser resolvidos. Para os casos específicos de que aqui se tratou, confiram-se, especialmente, na conclusão, os enunciados RP2.1.2, de um lado, e RP1.1.4, de outro. 


\section{CONCLUSÃO}

Ao termo deste trabalho, resumimos em tópicos breves as principais conclusões da investigação.

As mais relevantes conclusões dos capítulos 1 e 2 podem ser sumuladas em função da numeração adotada no corpo do próprio texto:

1. O CPC/2015 é, como o CPC/1973, adepto da teoria da relação jurídica, vista como decomponível em uma série de posições jurídicas, perspectiva até mesmo reforçada em função de dispositivos como os arts. $7^{\circ}$ e 190.

2. A categoria de ônus vem incorporada, inclusive no texto legal, de acordo com modelo que não se presta a caracterizá-la como posição jurídica, uma vez que configura imperativo hipotético, e não categórico, em suma, um mero interesse, resultando a confusão entre categorias de posições jurídicas e categorias de posições de outra natureza em incertezas relativas ao regime jurídico.

3. A impugnação especificada dos fatos é, no regime do CPC/2015, em geral, um dever e, excepcionalmente, uma faculdade, no caso do CPC/2015, art. 341, par. ún., categorias que são necessariamente desenhadas a partir de um referencial teórico suficientemente claro; no caso, designa-se por dever a situação passiva do sujeito que, em face de uma valoração do comportamento pelo ordenamento jurídico, tem o imperativo, em face de outrem, de colaborar para a realização da posição dela correlata, um direito; caso não colabore, sofrerá sanção, noção que, por sua vez, também precisa ser referida a um marco teórico, tendo como conteúdo mínimo a atribuição de valoração negativa, pelo ordenamento jurídico, ao comportamento indesejado.

4. Há persistente tensão no direito luso-brasileiro, identificável ao menos desde o século XVIII, entre a compreensão da impugnação especificada como dever ou como faculdade jurídica.

5. Essa tensão está radicada na contraposição entre dois valores no seio da tradição retórica ocidental, os valores da verdade e da liberdade. 
6. Na retórica clássica, predominava o valor liberdade, a despeito de as tensões continuarem latentes, de modo que a impugnação especificada dos fatos pelo litigante no seio de um processo judicial apenas podia ser concebida como faculdade, atrelada às estratégias do litigante que queria vencer o processo, mas não como dever apto a ser sancionado, isso porque o ordenamento não valorava negativamente a conduta do litigante que não impugnava especificadamente alegação do adversário.

7. Há uma mudança sistemática com os movimentos concomitantes de publicização do processo e de cristianização da retórica, de que resulta a formulação do processo romanocanônico, em que tem primazia o valor verdade sobre o valor liberdade e em que, correspondentemente, a impugnação especificada dos fatos aparece como um dever dos litigantes, suportado por uma ampla gama de sanções, especialmente por pronunciamentos mandamentais do juízo; é, portanto, circunstancial de um modelo preclusivo que a sanção se projete na admissão da veracidade dos fatos.

8. No processo de absorção do direito romano-canônico pelos iura propria europeus, e notadamente pelo processo luso, desde o século XIII, estrutura-se regime que concebe a impugnação especificada como dever, ainda que, no curso dos últimos séculos da modernidade, notadamente a partir de meados do século XVII, esse dever venha atenuado e mesmo desapareça, não necessariamente pelo desprestígio do valor verdade, mas por uma diversa economia dos atos processuais, com maior ênfase para a atividade probatória que para os atos postulatórios; é, portanto, circunstancial de um modelo centrado nos atos postulatórios que o valor verdade se traduza em dever de impugnação especificada dos fatos.

9. O Brasil independente herda de Portugal a referida tensão, mas, no contexto do século XIX, produz uma viragem em direção ao valor liberdade, reinterpretado nos moldes do liberalismo moderno, que passa a ser forte vetor axiológico do processo, sob o modelo das codificações liberais europeias, e assim trata a impugnação especificada preferencialmente como faculdade; a esse modelo contrapõe-se, no século XX, um modelo de processo social, radicado, em última instância, na codificação austríaca e associado à corrente da modernidade que é crítica ao liberalismo, modelo que penetra no Brasil decididamente a partir do CPC/1939, a partir de quando a impugnação especificada vai redesenhada, ainda uma vez, como dever. 
Conforme visto, foi possível, pelo esforço analítico empreendido nos capítulos 3 e 4, a partir premissas assentadas nos capítulos 1 e 2 , formular um conjunto de enunciados normativos que descrevem o dever de impugnação especificada dos fatos tal qual ele se extrai de nosso ordenamento. Uma apresentação prévia do regime jurídico que aqui se esboça fora já apresentada no item 14, em conclusão ao capítulo 3.

O que propomos a seguir, conforme já anunciado na Introdução desta investigação e no próprio item 14, é sua apresentação estruturada e completa, remetendo, por meio das referências em negrito, após o fim de cada enunciado, ao item específico do trabalho em que está desenvolvida a argumentação que dá suporte ao que, em cada ponto, vem sumulado.

É, assim, o seguinte o regime da impugnação especificada dos fatos no processo civil brasileiro:

(fundamento do dever de impugnação especificada dos fatos)

RF1. O dever de impugnação especificada dos fatos é um dos deveres cooperativos que emanam do princípio-garantia do contraditório substancial, que, em um marco de processo publicístico, exige, e não faculta - vale dizer, valora positivamente sua ocorrência e negativamente sua não-ocorrência - o diálogo processual. $(16,20)$

RF1.1. Para ser eficaz, a impugnação de alegações de fato, não apenas na contestação, mas em todo ato que ataca alegações que possam ser tomadas pelo juiz como fundamento decisório, deve maximizar um contraditório efetivo e substancial. $\mathbf{( 2 0 , 2 1 )}$

RF1.2. O contraditório efetivo apenas admite alegações conformes à boafé objetiva, sendo vedado o abuso do direito de defesa sob as vestes de uma impugnação especificada. (17.3)

RF1.2.1. É conduta ímproba, a ser sancionada com imposição de multa, a impugnação de alegação de fato que se sabe (ou se deve 
saber, segundo um padrão de boa-fé objetiva) ser conforme às alegações do autor. (17.3)

\section{(objeto do dever de impugnação especificada dos fatos)}

RG1. O dever de impugnação especificada dos fatos incide sobre todas as proposições simples enunciadas pelo autor, desde que cada proposição seja necessária para preencher uma figura de fato normativa (um fato jurídico previsto no ordenamento) e desde que, em seu conjunto, essas proposições sejam suficientes para preenchê-la (caso contrário, a própria petição é inepta). (11.1)

Nesses termos e nesses limites:

RG1.1. Incide dever de impugnação sobre alegação de fato jurídico, incluídos os fatos complementares (especificadores da figura do fato). (11.4)

RP1.1.1. Não se admite restrição de cognição horizontal às defesas diretas. (22.2)

RP1.1.1.1. Eventuais restrições de cognição horizontal à defesa direta apenas podem espelhar restrições homólogas aos fundamentos que podem ser invocados pelo autor em suas alegações. (22.5)

RP1.1.2. A impugnação especificada de alegação de fato jurídico pelo litisconsorte torna sem efeito a ausência de impugnação especificada pelo outro, para fins de admissão do fato como verdadeiro. (17.2.2)

RP1.1.3. A ausência de impugnação especificada não tem o condão de excluir da atividade probatória os fatos jurídicos inverossímeis. (17.2.2)

RP1.1.4. Integra o objeto da impugnação especificada dos fatos o conteúdo dos documentos juntados à inicial desde que as proposições do autor façam remissão direta a elas e na medida da especificação dessa remissão; em caso contrário, caso o juiz indique que o conteúdo do documento pode ser levado em consideração para a 
decisão, desfaz-se a preclusão e se permite ao réu manifestar-se sobre o ponto, sem que incida dever de impugnação especificada (cf. RG 1.3). (17.2.1)

RP1.1.5. A mera juntada de documentos pelo réu não importa no cumprimento do dever de impugnação especificada, mas não invalida seu uso como prova no processo. (17.2.1)

RG1.2. Não incide dever de impugnação sobre alegação de fato simples, incluídos os fatos indiciários (instrumentais para o raciocínio judicial). (11.4)

RG1.3. Quando, nos limites admitidos no processo, um fato afirmado pelo autor na inicial muda de qualificação, de simples para jurídico, o debate é reaberto, e passa a incidir, desobstruída a preclusão, o dever de impugnação especificada. (11.4)

RG1.3.1. O exercício de poderes instrutórios pelo juiz apenas gera dever de impugnação especificada, desobstruindo preclusões, se se trata de fatos que concretizam a figura do fato, recortando-a em mais elementos ou sub-elementos do que na fase postulatória (fatos complementares), não os gerando se incidem sobre fatos simples. (11.4)

RG1.3.2. Se proposição de fato simples na petição inicial, segundo a percepção do juiz, puder efetivamente ser tomada por indiciária, de modo a integrar o raciocínio decisório, cabe ao juiz desobstruir as preclusões e reabrir o diálogo processual para amplo debate, embora não incida no caso dever de impugnação especificada, que resultaria na provocação de efeito idêntico ao da confissão por iniciativa do juiz. (11.4)

RP1.3.3. Se há, dentro dos limites autorizados pelo ordenamento, alteração objetiva da demanda, incidirá, para o réu, dever de impugnação especificada dos fatos, com prazo de manifestação não inferior ao da contestação, a partir do momento da alteração. (17.1.2) 
RP1.3.4. Após a preclusão do prazo da impugnação especificada, a parte pode confessar fato que havia anteriormente impugnado, mas não pode se aproveitar da confissão para impugnar fato que não impugnou no momento oportuno. (18.3)

RP1.4. É possível a impugnação especificada de fato tardia, após o prazo e até o fim do processo, se o réu alegar e provar que a ausência de impugnação especificada, no momento previsto, decorreu de falsa percepção da realidade (erro, coação...) que não lhe possa ser imputada (e.g., erro grosseiro por falta de diligência). (18.3)

RP1.5. A ausência de impugnação especificada (cf., supra, RG1.3), desde que não intervenha alguma das hipóteses de desfazimento de preclusões, impede a realização de atividade probatória sobre aquele fato, tendo se estabilizado o seu caráter incontroverso. (17.2.2)

(conteúdo do dever de impugnação especificada dos fatos)

RG2. Se há fato jurídico (em sentido lato) que aparece - tipicamente, isto é, de acordo com a categoria, não com cada evento concreto do mundo - à consciência do réu (atos jurídicos stricto sensu, negócios jurídicos, atos-fatos jurídicos), o dever de impugnação especificada exige que ele se pronuncie positivamente sobre tal fato, narrando-o tal qual aparece à sua consciência, sem omissões que importem em sua descaracterização (dever de completude); se há fato jurídico que não aparece - tipicamente - à consciência do réu (fatos jurídicos stricto sensu ou atos de terceiros), o dever de impugnação especificada se cumpre com a mera declaração de desconhecimento. (12.1, 18.2, 21, 22.3)

RP2.1. A impugnação especificada, no caso dos fatos jurídicos que pertencem à esfera perceptiva do réu, deve ser determinada quando essa determinação não tem razão de escusa, no que se inclui a indicação precisa daqueles elementos necessários à individuação dos referentes, como coordenadas de tempo, espaço, quantidade e qualidades essenciais (ineficácia das respostas evasivas). (17.1.1) 
RP2.1.1. Não se desincumbe do dever de impugnação especificada o réu alegando falta de clareza das alegações do autor, mesmo o fazendo especificadamente; no entanto, não se poderá exigir do réu maior grau de especificidade do que aquele que se encontra nas alegações que integram a petição inicial, devendo-se ter por especificada impugnação que tenha o mesmo grau de clareza e determinação que a petição inicial. (17.1.1)

RP2.1.2. Toda vez que o réu impugna parcialmente um valor, ele deve declinar o valor correto e demonstrar os fundamentos do cálculo. $(21,22.6)$

RG2.2. Não há descumprimento do dever de impugnação especificada, por falta de contranarrativa fática, quando sobre o fato jurídico que aparece tipicamente à consciência do réu incide uma razão de escusa (art. 388 do CPC/2015). Como, no entanto, esses fatos podem ser confessados (não incidindo o art. 341, I), é necessária a manifestação do réu para os impugnar, bastando, para fins de eficácia, a afirmação de que o réu impugna tais fatos. Sua negação, no entanto, caso sejam verdadeiros, pode atrair a incidência dos arts. 77, I, e 80, II, do CPC/2015. (12.1)

RG2.3. O réu pode se desincumbir do dever de impugnação especificada sem oferecer qualquer contranarrativa fática se não reconhece em absoluto a existência dos fatos narrados pelo autor, caso em que afirma saber que nada ocorreu no mundo dos eventos da vida que possa corresponder, ainda que imperfeitamente, àquilo que foi afirmado pelo autor. (12.2)

RG2.3.1. Fica, no entanto, vedada essa via caso a petição inicial seja instruída com documento que contém declaração de vontade ("instrumento" ad substantiam ou ad probationem) do réu conexa com as alegações de fato do autor, a menos que o réu afirme a falsidade material ou ideológica do referido documento. (12.2)

RP2.4. Ocorre abuso de direito quando o réu impugna especificadamente alegação de fato do autor por meio de sucessivos recortes da figura de fato desenhada na inicial, sem que esses recortes sejam em tese aptos a afastar 
os elementos da figura de fato necessários e suficientes para sustentar a pretensão do autor. (cf., supra, RF1.2) (17.3)

(impugnação especificada dos fatos por prejudicialidade lógica)

RG3. Impugnada eficazmente a alegação prejudicial, fica automaticamente impugnada também, por necessidade lógica, a alegação prejudicada, de modo que ambas ficam controvertidas, dando ensejo à produção de prova. $(\mathbf{1 3}, \mathbf{1 9})$ 


\section{BIBLIOGRAFIA}

D’AGOSTINO, Francesco. Sanzione (teoria generale). In: Francesco SANTOROPASSARELLI (dir.). Enciclopedia del Diritto: volume 41, rivendicazioneseparazione. Milano: Giuffrè, 1989, p. 303-328.

. La sanzione nell'esperienza giuridica. 5.ed. Torino: G. Giappichelli, 1999.

AGUIAR, João Carlos Pestana de. Comentários ao Código de Processo Civil: volume 4, artigos 332 a 443. São Paulo: RT, 1974.

ALBERTO dos REIS, José. Breve Estudo sobre a Reforma do Processo Civil e Comercial. 2.ed. Coimbra: Coimbra Editora, 1929.

. Código de Processo Civil Anotado: volume 2, artigos $409^{\circ}$ a $486^{\circ}$. 3.ed. Coimbra: Coimbra Editora, 1949.

. Código de Processo Civil Anotado: volume 3, artigos $487^{\circ}$ a $549^{\circ}$. Coimbra: Coimbra Editora, 1950.

. Comentários ao Código de Processo Civil: volume 2. Coimbra: Coimbra Editora, 1945.

. A oralidade no processo civil português. In: Francisco MORATO et alii. Processo Oral. Rio de Janeiro: Forense, 1940, p. 111-22.

. Processo de execução: volume 2. Coimbra: Coimbra Editora, 1954.

. Processos especiais: volume 1. Coimbra: Coimbra Editora, 1982.

D’ALBUQUERQUE, Lydio Marianno. Tratado das Excepções. Pernambuco: Typographia Central, 1880.

ALCALÁ-ZAMORA y CASTILLO, Niceto. Evolución de la doctrina procesal. In: ; Estudios de teoría general e historia del proceso (1945-1972): tomo 2. México: Universidad Nacional Autõnoma de México, 1974, p. 293-331.

ALEXANDER, Michael C. Oratory, Rhetoric, and Politics in the Republic. In: William DOMINIK; Jon HALL (ed.). A Companion to Roman Rhetoric. Oxford: Blackwell, 2007, p. 98-108.

D’ALMEIDA, Luís Duarte. Fundamental Legal Concepts: the Hohfeldian framework. Philosophy Compass, n. 11(10), p. 554-569, 2016.

ALMEIDA COSTA, Mário Júlio de. História do Direito Português. 3.ed. Coimbra: Almedina, 2005.

ALTIMARIO, Blasio. Tractatus de nullitatibus: tomo 1. Köln: Wilhelm Metternich, 1720.

ALVARO de OLIVEIRA, Carlos Alberto. O juiz e o princípio do contraditório. Revista de Processo, São Paulo, n. 73, p.-7-14, jan.-mar. 1994. 
Do formalismo no processo civil. 2.ed. São Paulo: Saraiva, 2003.

; Galeno LACERDA. Comentários ao Código de Processo Civil: volume 8, tomo 2, artigos 813 a 889. 2.ed. Rio de Janeiro: Forense, 1991.

; Daniel MITIDIERO. Curso de Processo Civil: volume 2, processo de conhecimento. São Paulo: Atlas, 2012.

ALVIM NETTO, Manoel Arruda: v. ARRUDA ALVIM NETTO, Manoel

AMADEO, Rodolfo da Costa Manso Real. Embargos de terceiro: legitimidade passiva. São Paulo: Atlas, 2006.

AMARAL SANTOS, Moacyr. Comentários ao Código de Processo Civil: volume 4, artigos 332 a 475. 7.ed. Rio de Janeiro: Forense, 1994.

. Primeiras linhas de direito processual civil: volume 2 São Paulo: Max Limonad, 1962.

Primeiras linhas de direito processual civil: volume 2. 20.ed. São Paulo: Saraiva, 1999

Prova judiciária no cível e comercial: volume 1. 4.ed. São Paulo: Max Limonad, 1970.

. Prova judiciária no cível e comercial: volume 2. 4.ed. São Paulo: Max Limonad, 1971.

AMENDOREIRA JR., Sidnei. Depoimento pessoal e confissão no Novo CPC. In: Marcos Félix JOBIM; William Santos FERREIRA. Direito Probatório. Salvador: Juspodivm, 2015, p. 695-712 (Coleção Grandes Temas do Novo CPC, coordenada por Fredie Didier Jr., volume 5).

AMERICANO, Jorge. Do abuso do direito no exercício da demanda. 2.ed. São Paulo: Saraiva, 1932.

. Comentários ao Código do Processo Civil do Brasil: volume 1, artigos 1 a 290. São Paulo: Saraiva, 1940.

Commentarios ao Codigo do Processo Civil e Commercial do Estado de São Paulo: $1^{\circ}$ volume, arts. 1 a 261. São Paulo: Saraiva, 1934.

ANAGNOSTOPOUlOS, Georgios (ed.). A Companion to Aristotle. Oxford: WileyBlackwell, 2009.

ANDRADE, Odilon de. Código do Processo Civil e Commercial do Districto Federal: Decreto n. 16.752, de 31 de dezembro de 1924, annotado de accôrdo com a doutrina, a legislação e a jurisprudência, $1^{\circ}$ volume. Rio de Janeiro: Officinas Graphicas d'O Social, 1927. 
ANTUNES VARELA, [João de Matos]; J[osé] Miguel BEZERRA; [José Joaquim] SAMPAIO e NORA. Manual de Processo Civil. 2.ed. Coimbra: Coimbra Editora, 1985.

APRIGLIANO, Ricardo de Carvalho. Comentário ao artigo 349. In: Cassio Scarpinella BUENO (coord.). Comentários ao Código de Processo Civil: volume 2. São Paulo: Saraiva, 2017, p. 133-34.

ARAÚJO, Fábio Caldas de. Curso de Processo Civil: tomo 1, parte geral. São Paulo: Malheiros, 2016.

. Curso de Processo Civil: tomo 3, procedimentos especiais. São Paulo: Malheiros, 2018.

ARAÚJO, José Henrique Mouta; Leonardo Carneiro da CUNHA (coord). Advocacia Pública. Salvador: Juspodivm, 2015 (Coleção Repercussões do Novo CPC, volume 3, coordenada por Fredie Didier Jr.).

ARAÚJO CINTRA, Antonio Carlos de. Comentários ao Código de Processo Civil: volume 4, artigos 332 a 475. 3.ed. Rio de Janeiro: Forense, 2008.

; Ada Pellegrini GRINOVER; Cândido Rangel DINAMARCO. Teoria geral do processo. 1.ed. São Paulo: RT, 1974.

ARAÚJO JÚNIOR, Gediel Claudino de. A resposta do réu no processo civil: teoria e prática. Rio de Janeiro: Forense, 1983.

ARISTOTE. Catégories. Ed. e trad. Richard Bodéüs. Paris: Les Belles Lettres, 2002.

Organon: I, Catégories - II, De l'interprétation. Trad. e notas Jules Tricot. Paris: J. Vrin, 1946.

ARISTOTELE. Retorica. Ed. e Trad. Marco Dorati. Milano: Mondadori, 1996.

ARISTOTLE. On Interpretation. In: The Categories - On Interpretation - Prior Analytics. Ed. e trad. Harold P. Cooke. Cambridge/London: Harvard University Press/William Heinemann, 1983, p. 111-79, (Coleção The Loeb Classical Library, editada por G. P. Goold, volume 325).

. The Metaphysics: books I-IX. Ed. e trad. Hugh Tredennick. London/New York: William Heinemann/G. P. Putnam, 1933, (Coleção The Loeb Classical Library, editada por G. P. Goold, volume 271).

. Posterior Analytics. In: __ Posterior Analytics - Topica. Ed. e trad. Hugh Tredennick. Cambridge/London: Harvard University Press, 1960, p. 1-261 (Coleção The Loeb Classical Library, editada por G. P. Goold, volume 391).

Prior Analytics. In: The Categories - On Interpretation - Prior Analytics. Ed. e trad. Hugh Tredennick. Cambridge/London: Harvard University Press/William Heidemann, 1983, p. 181-531 (Coleção The Loeb Classical Library, editada por G. P. Goold, volume 325). 
ARMELIN, Donaldo. Embargos de terceiro. São Paulo: Saraiva, 2017.

ARRUDA ALVIM, Eduardo. Comentário ao artigo 1021. In: C. S. BUENO (coord.). Comentários ao Código de Processo Civil: volume 4, artigos 926 a 1072, parte especial. São Paulo: Saraiva, 2017, p. 469-473.

ARRUDA ALVIM NETTO, Manoel. Código de Processo Civil Comentado: volume 2, artigos $7^{\circ}$ a 49. São Paulo: RT, 1975.

Manual de Direito Processual Civil: teoria geral do processo e processo de conhecimento. 17.ed. São Paulo: RT, 2017.

ASSIS, Araken de. Manual da Execução. 18.ed. São Paulo: RT, 2016.

Manual dos Recursos. 8.ed. São Paulo: RT, 2016.

Processo Civil Brasileiro: volume 1, parte geral, fundamentos e distribuição de conflitos. São Paulo: RT, 2015.

Processo Civil Brasileiro: volume 2, tomo 1, parte geral, institutos fundamentais. São Paulo: RT, 2015.

. Processo Civil Brasileiro: volume 2, tomo 2, parte geral, institutos fundamentais. São Paulo: RT, 2015

Processo Civil Brasileiro: volume 3, parte especial, procedimento comum, da demanda à coisa julgada. São Paulo: RT, 2016.

ATAIIDE JR; Jaldemiro Rodrigues de; Juliana Coelho Tavares da SILVA. Exibição de documentos: ônus ou dever da parte? In: Lucas Buril de MACÊDO; Ravi PEIXOTO; Alexandre FREIRE (org.). Provas. 2.ed. Salvador: Juspodivm, 2016, p. 663-81 (Coleção Novo CPC: doutrina selecionada, coordenada por Fredie Didier Jr., volume 3).

AULU-GELLE. Les Nuits Attiques: III, livres XIV à XX. Ed. e Trad. Maurice Mignon. Paris: Librairie Garnier Frères, 1934.

AURELLI, Arlete Inês. Comentário ao art. 341. In: Lenio Luiz STRECK; Dierle NUNES; Leonardo Carneiro da CUNHA (org.). Comentários ao Código de Processo Civil. São Paulo: Saraiva, 2016, p. 498-99.

AZEVEDO, Antonio Junqueira de: v. JUNQUEIRA de AZEVEDO, Antonio

AZEVEDO MARQUES, José Manuel de. Acções de despejo e alugueres: locação de predios. 4.ed. São Paulo: Saraiva, 1930.

BALENA, Gianpiero. Istituzioni di diritto processuale civile: volume 2, il processo ordinario. 4.ed. Bari: Cacucci, 2017.

BAPTISTA, Francisco de Paula: v. PAULA BAPTISTA, Francisco de 
BAPTISTA da SILVA, Ovídio Araújo. Comentários ao Código de Processo Civil: volume 13, artigos 890 a 981, dos procedimentos especiais. São Paulo: RT, 2000.

Curso de Processo Civil: volume 1, tomo 1. 8.ed. Rio de Janeiro: Forense, 2008. Juizado de Pequenas Causas. Porto Alegre: LeJur, 1985. . Jurisdição, Direito Material e Processo. Rio de Janeiro: Forense, 2008.

Processo de conhecimento e procedimentos especiais. In: . Da sentença liminar à nulidade da sentença. Rio de Janeiro: Forense, 2001, p. 93-105.

BARBOSA, Emmanuel. Remissiones Doctorum de Officiis Publicis, Iurisdictione, et Ordine Iudiciario. Lisboa: Typis Petri Craesbeeck, 1620.

BARBOSA MOREIRA, José Carlos. Ação de consignação em pagamento. Possibilidade de discussão do valor do débito fundada em divergência na interpretação do contrato. Apelação cível no 11.267. In: Direito Aplicado I: acórdãos e votos. 2.ed. Rio de Janeiro: Forense, 2001, p. 51-58.

Anotações sobre o título "Da prova" do Novo Código Civil. In: . Temas de direito processual: nona série. São Paulo: Saraiva, 2007, p. 141-58.

Antecedentes da reforma processual e sistemática geral do novo Código. In: . Estudos sobre o Novo Código de Processo Civil. Rio de Janeiro: Liber Juris, 1974, 9-43.

. Le Code-Modèle de Procédure Civile pour l'Amérique Latine de l'Institut IbéroAméricain de Droit Processuel. In: série. São Paulo: Saraiva, 2001, p. 191-200. Temas de direito processual: sétima

- Il Codice di Procedura Civile dello Stato della Città del Vaticano come fonte storica del diritto brasiliano. In: Temas de direito processual: quinta série. São Paulo: Saraiva, 1994, p. 189-99.

Os Códigos de Processo Civil de 1939 e de 1973: contrastes e confrontos. In: . Estudos sobre o Novo Código de Processo Civil. Rio de Janeiro: Liber Juris, 1974, p. 44-67.

. Comentários ao Código de Processo Civil: volume 5, artigos 476 a 565. Rio de Janeiro/São Paulo: Forense, 1974.

. Comentários ao Código de Processo Civil: volume 5, artigos 476 a 565. 14.ed. Rio de Janeiro: Forense, 2008.

A influência do direito processual civil alemão em Portugal e no Brasil. In:

Temas de direito processual: quinta série. São Paulo: Saraiva, 1994, p. 177-88.

Julgamento e ônus da prova. In: . Temas de direito processual: segunda série. 2.ed. São Paulo: Saraiva, 1988, p. 73-82. 
A motivação das decisões judiciais como garantia inerente ao estado de direito.

In: Temas de direito processual: segunda série. 2.ed. São Paulo: Saraiva, 1988, p. 83-95.

. O novo processo civil brasileiro: exposição sistemática do procedimento. 26.ed. Rio de Janeiro: Forense, 2008.

As presunções e a prova. In: Temas de direito processual: primeira série. São Paulo: Saraiva, 1977, p. 55-71.

. Il Progetto Carnelutti e il Codice di Procedura Civile brasiliano. In: Temas de direito processual: quinta série. São Paulo: Saraiva, 1994, p. 201-15.

. O que deve e o que não deve figurar na sentença. In: Temas de Direito Processual: oitava série. São Paulo: Saraiva, 2004, p. 117-24. Questões prejudiciais e coisa julgada. Rio de Janeiro: Do autor, 1967.

Questões velhas e novas em matéria de classificação das sentenças. In: Temas de Direito Processual: oitava série. São Paulo: Saraiva, 2004, p. 125-42. A responsabilidade das partes por dano processual no direito brasileiro. In: Temas de direito processual: primeira série. São Paulo: Saraiva, 1977, p. 16-35. - A revelia no direito alemão e a reforma do processo civil brasileiro. In: Estudos sobre o Novo Código de Processo Civil. Rio de Janeiro: Liber Juris, 1974, p. 134-47.

_. Saneamento do processo e audiência preliminar. In: Temas de direito processual: quarta série. São Paulo: Saraiva, 1989, p. 105-44.

BARROS, Hamilton de Moraes e. Comentários ao Código de Processo Civil: volume 9, artigos 946 a 1102. 4.ed. Rio de Janeiro: Forense, 1993.

BARROS, Henrique da Gama: v. GAMA BARROS, Henrique da

BARROSO, Darlan; Brunno Pandori GIANCOLI; Marcelo Romão MARINELLI. Prática processual civil. 2.ed. São Paulo: RT, 2014.

BARTHES, Roland. L'ancienne rhétorique: aide-mémoire. Communications, Paris, n. 16, p. $172-229,1970$.

BEAUMANOIR, Philippe de. Coutumes de Beauvaisis: tome premier. Ed. Am. Salmon. Paris: Alphonse Picard et Fils, 1899.

BEDAQUE, José Roberto dos Santos. Efetividade do processo e técnica processual. São Paulo: Malheiros, 2006. Poderes instrutórios do juiz. 3.ed. São Paulo: RT, 2001. 
BELEZA, Maria dos Prazeres Pizarro. Ónus da impugnação. In: O Novo Processo Civil: textos e jurisprudência, caderno 5. Centro de Estudos Judiciários, 2015, p. 215233.

BELlOMO, Mario. The Common Legal Past of Europe: 1000-1800. Trad. Lydia G. Cochrane.Washington, DC: The Catholic University of America Press, 1995.

BELTRÁN, Jordi Ferrer. Prova e verdade no Direito. Trad. Vitor de Paula Ramos. São Paulo: RT, 2017.

BENEDUZI, Renato. Comentários ao Código de Processo Civil: volume 2, artigos 70 ao 187. São Paulo: RT, 2016 (Coleção Comentários ao Código de Processo Civil, dirigida por Luiz Guilherme Marinoni e coordenada por Sérgio Cruz Arenhart e Daniel Mitidiero).

BETHMANN-HOLLWEG, August von. Der Civilprozess des gemeinen Rechts: Erster Band, der römische Civilprozess, 1, legis actiones. Bonn: Adolph Marcus, 1864.

. Der germanisch-romanische Civilprozess im Mittelalter: Dritter Band, vom zwölften bis fünfzehnten Jahrhundert. Bonn: Adolph Marcus, 1874

BETTI, Emilio. Corso di Istituzioni di Diritto Romano: volume primo, parte generale, escluso il processo, anno accademico 1927-28. Padova: CEDAM, 1928.

Diritto processuale civile italiano. 2.ed. Roma: Foro Italiano, 1936.

. Dovere giuridico: a) cenni storici e teoria generale. In: Francesco CALASSO (coord.). Enciclopedia del Diritto: volume 14. Milano: Giuffrè, 1965, p. 53-58.

. Istituzioni di diritto romano: volume primo. 2.ed. Padova: CEDAM, 1947.

. Teoria generale del negozio giuridico. 2.ed. Torino: UTET, 1950.

BISCARDI, Arnaldo. Cenni sulla procedura giustinianea 'per libellos'. In: . Aspetti del fenomeno processuale nell'esperienza giuridica romana. 2.ed. Milano: Cisalpino-Goliardica, 1978, p. 307-313.

BISHOP, Richard W.; Johan LEEMAN; Hajnalka TAMAS (ed.). Preaching after Easter: Mid-Pentecost, Ascension and Pentecost in Late Antiquity. Leyden: Brill, 2016.

BOBBIO, Norberto. Direito e Estado no Pensamento de Emanuel Kant. Trad. Alfredo Fait. Brasília: Editora Universidade de Brasília, 1984 (Coleção Pensamento Político, volume 63).

. Sanzione. In: Antonio AZARA; Ernesto EULA (dir.). Novissimo Digesto Italiano: volume 16. Torino: UTET, 1969, p. 530-40.

. Teoria della norma giuridica. Torino: G. Giappichelli, 1958.

BONDIOLI, Luis Guilherme Aidar. Comentário ao art. 341. In: C. S. BUENO (coord.). Comentários ao Código de Processo Civil: volume 2, arts. 318-538, parte especial. São Paulo: Saraiva, 2017, p. 95-98. 
BONFANTE, Pietro. Storia del diritto romano: volume primo. 4.ed. Torino: UTET, 1934.

BONIZZI, Marcelo José Magalhães. Fundamentos da prova civil: teoria geral da prova e provas em espécie segundo o Novo CPC. São Paulo: RT, 2017.

BONS, Jeroen A. E.. Gorgias the Sophist and Early Rhetoric. In: Ian WORTHINGTON (ed.). A Companion to Greek Rhetoric. Oxford: Blackwell, 2007, p. 37-46.

BONUMÁ, João. Direito Processual Civil: volume 2. São Paulo: Saraiva, 1946.

BORGES da ROSA, Innocencio. Processo Civil e Comercial Brasileiro: volume 1. Porto Alegre: Globo, 1940.

BORTOLAI, Edson Cosac. Da ação de prestação de contas. São Paulo: Saraiva, 1981.

BOZZO, Guilherme Tambarussi. Inatividade das partes no processo civil brasileiro. Salvador: Juspodivm, 2018.

- Repercussões do Novo Código de Processo Civil nos procedimentos da lei de locações. In: E. J. da F. COSTA; H. V. M. SICA. Legislação processual extravagante. Salvador: Juspodivm, 2016, p. 177-206 (Coleção Repercussões do Novo $C P C$, volume 9, coordenada por Fredie Didier Jr.).

BRAET, Antoine. Variationen zur Statuslehre von Hermagoras bei Cicero. Rhetorica: a Journal of the History of Rhetoric, n. 7(3), p. 239-59, 1989.

BRAGA, Antônio Pereira. Exegese do Código de Processo Civil: volume 2, crítica, interpretação, jurisprudência. Rio de Janeiro: Max Limonad, s/d.

BRAUN, Johann. Lehrbuch des Zivilprozeßrechts: Erkenntnisverfahren. Tübingen: Mohr Siebeck, 2014.

BRAUW, Michael de. The Parts of the Speech. Ian WORTHINGTON (ed.). A Companion to Greek Rhetoric. Oxford: Blackwell, 2007, p. 187-202.

BRETONE, Mario. Storia del Diritto Romano. Roma/Bari: Laterza, 2012.

BRUNETTI, Giovanni. Norme e regole finali nel diritto. Torino: UTET, 1913.

BRUNNER, Heinrich. Deutsche Rechtsgeschichte: Zweiter Band. Leipzig: Duncker \& Humblot, 1892.

BRUTAU, José Puig. Hecho jurídico. In: Carlos E. MASCAREÑAS (dir.). Nueva Enciclopedia Jurídica: tomo 10. Barcelona: Francisco Seix, 1960, p. 836-38.

BUENO, Cassio Scarpinella. Comentários ao Código de Processo Civil: volume 10, da liquidação e do cumprimento de sentença, arts. 509-538. São Paulo: Saraiva, 2018 (Coleção Comentários ao Código de Processo Civil, coordenada por José Roberto F. GOUVÊA; Luís Guilherme A. BONDIOLI e João Francisco N. da FONSECA). 
Curso Sistematizado de Direito Processual Civil: volume 1, teoria geral do direito processual civil, parte geral do Código de Processo Civil. 9.ed. São Paulo: Saraiva, 2018.

. Curso Sistematizado de Direito Processual Civil: volume 2, tomo 1, procedimento comum, ordinário e sumário. 7.ed. São Paulo: Saraiva, 2014.

. Curso Sistematizado de Direito Processual Civil: volume 2, tomo 2, procedimentos especiais do Código de Processo Civil, juizados especiais. 2.ed. São Paulo: Saraiva, 2013

. Curso Sistematizado de Direito Processual Civil: volume 3, tutela jurisdicional executiva, 7.ed. São Paulo: Saraiva, 2014.

Curso Sistematizado de Direito Processual Civil: volume 4, tutela antecipada, tutela cautelar, procedimentos cautelares específicos. 6.ed. São Paulo: Saraiva, 2014.

. Manual de Direito Processual Civil: volume único. 4.ed. São Paulo: Saraiva, 2018.

Projetos de Novo Código de Processo Civil comparados e anotados: Senado Federal, PLS n. 166/2010 e Câmara dos Deputados, PL n. 8.048/2010. São Paulo: Saraiva, 2014.

BUENO, José Antônio Pimenta: v. PIMENTA BUENO, José Antônio

BÜLOW, Oskar von. Die Lehre von den Processeinreden und die Processvoraussetzungen. Giessen: Emil Roth, 1868.

BUZAID, Alfredo. Ação de consignação em pagamento (1968). In: . Estudos e Pareceres de Direito Processual Civil. Ed. Ada Pellegrini Grinover e Flávio Luiz Yarshell. São Paulo: RT, 2002, p. 171-81.

. Da ação renovatória e das demais ações oriundas de contrato de locação de imóveis destinados a fins comerciais: volume 2. 3.ed. São Paulo: Saraiva, 1988.

. Anteprojeto de Código de Processo Civil. Rio de Janeiro: Imprensa Nacional, 1964.

. A influência de Liebman no direito processual civil brasileiro. Revista da Faculdade de Direito, Universidade de São Paulo, São Paulo, n. 72 (1), p. 131-52, 1977.

. Do ônus da prova. Revista de Direito Processual Civil, São Paulo, n. 4, p. 5-24, 1964.

. Paula Batista: atualidades de um velho processualista. São Paulo, s/e, 1950.

BYDLINSKI, Unentbehrlichkeit und Grenzen methodischen Rechtdenkens. Archiv für die civilistische Praxis, n. 188 (5), p. 447-488, 1988.

CABRAL, Antonio Vanguerve: v. VANGUERVE CABRAL, Antonio 
CADIET, Loïc; Emmanuek JEULAND. Droit judiciaire privé. 8.ed. Paris: LexisNexis, 2013.

CAENEGEM, Raoul Charles van. Chapter 2: European Civil Procedure. In: Mauro CAPPELlETTI (ed.). Civil Procedure. Tübingen: J. C. B. Mohr, 1982, p. 1-115 (Coleção International Encyclopedia of Comparative Law, organizada pela International Association of Legal Science, volume 16).

CALAMANDREI, Piero. Conseguenze della mancata esibizione di documenti in giudizio. Rivista di diritto processuale, n. 13, p. 291ss, 1936.

. Istituzioni di diritto processuale civile secondo il nuovo codice: parte prima, premesse storiche e sistematiche. 2.ed. Padova: CEDAM, 1943.

. Il processo come situazione giuridica. In:___. Opere giuridiche: volume primo. Ed. Mauro Cappelletti. Napoli: Morano, 1965, p. 177-86.

CALASSO, Francesco. Medio Evo del Diritto: I - le fonti. Milano: Giuffrè, 1954.

CALMON de PASSOS, José Joaquim. Comentários ao Código de Processo Civil: volume 3, artigos 270 a 331. 3.ed. Belo Horizonte/Rio de Janeiro: Forense, 1979.

. Comentários ao Código de Processo Civil: volume 3, artigos 270 a 331. 9.ed. Rio de Janeiro: Forense, 2004.

. Da revelia do demandado. Salvador: Progresso, 1960.

Teoria geral dos procedimentos especiais. In: Ensaios e artigos: volume 2. Salvador: Juspodivm, 2016, p. 205-13.

CÂMARA, Alexandre Freitas. Lições de Direito Processual Civil: volume 1. 25.ed. São Paulo: Atlas, 2014.

. O novo processo civil brasileiro. São Paulo: Atlas, 2015.

CÂMARA, José Gomes Bezerra. Subsídios para a história do direito pátrio: tomo III, 1822-1889. Rio de Janeiro: Brasiliana, 1966.

. Subsídios para a história do direito pátrio: tomo IV, 1889-1930. Rio de Janeiro: Brasiliana, 1967.

CÂMARA LEAL, Antônio Luiz da. Código do Processo Civil e Commercial do Estado de São Paulo Commentado. São Paulo: Livraria Academica Saraiva \& Cia, 1930.

. Do depoimento pessoal: theoria e pratica. São Paulo: Saraiva, 1923.

. Theoria e Pratica das Acçções: volume I, introdução, acção de família, acções reaes. São Paulo: Saraiva, 1923.

Theoria e Pratica das Acções: volume II, acções obrigacionaes. São Paulo: Saraiva, 1933. 
CAMARGO, Luiz Henrique Volpe. Comentário ao artigo 1021. In: Teresa Arruda Alvim WAMBIER et alii (org). Breves Comentários ao Novo Código de Processo Civil. São Paulo: RT, 2015, p. 2259-66.

CAMBI, Eduardo. A inexistência do ônus da impugnação específica para o consumidor. Revista de Processo, São Paulo, n. 129, p. 66-74, nov. 2005.

CAMINHA. Forma das elegações judiciaes. In: CAMINHA. Tractado da forma dos libellos. Coimbra: Antonio de Maris, 1558.

CAMMARATA, Angelo Ermanno. Il significato e la funzione del "fatto" nell'esperienza giuridica. In: Formalismo e sapere giuridico: studi. Milano: Giuffrè, 1963, p. 245-93.

CANARIS, Claus-Wilhelm. Pensamento sistemático e conceito de sistema na ciência do Direito [2a edição: 1987]. Trad. Antonio Menezes Cordeiro. 3.ed. Lisboa: Calouste Gulbenkian, 2002.

CANOTILHO, José Joaquim Gomes. Direito Constitucional e Teoria da Constituição. 7.ed. Coimbra: Almedina, 2003.

CAPPELLETTI, Mauro. La testimonianza della parte nel sistema dell'oralità: parte prima, contributo alla teoria della utilizzazione probatoria del sapere delle parti nel processo civile. Milano: Giuffrè, 1974.

CARNEIRO, Athos Gusmão. Audiência de instrução e julgamento e audiências preliminares. 8.ed. Rio de Janeiro: Forense, 1996.

CARNEIRO, Paulo Cezar Pinheiro. Comentários ao Código de Processo Civil: volume 9, tomo 1. 3.ed. Rio de Janeiro: Forense, 2003.

CARNELUTTI, Francesco. L'arte del diritto. Padova: CEDAM, 1949.

Diritto e Processo. Napoli: Morano, 1958.

Lezioni di diritto processuale civile: volume 1, introduzione. Padova: La Litotipo, 1926.

Lezioni di diritto processuale civile: processo di esecuzione, volume 1. Padova: CEDAM, 1929.

La prova civile: parte generale, il concetto giuridico della prova. Milano: Giuffrè, 1992.

. Progetto del Codice di Procedura Civile: parte prima, del processo di cognizione. Padova: CEDAM, 1926.

- Sistema di diritto processuale civile: volume 1, funzione e composizione del processo. Padova: CEDAM, 1936.

. Sistema del diritto processuale civile: volume 2, atti del processo. Padova: CEDAM, 1938. 
Teoria Generale del Diritto. 3.ed. Roma: Foro Italiano, 1951.

. Il valore della sanzione nel diritto. Rivista di diritto processuale, Padova, n. 10 (1), p. 237-48, 1955.

CAROATÁ, José Prospero Jehovah da Silva. Vademecum Forense. Rio de Janeiro: Eduardo \& Henrique Laemmert, 1866.

CARPES, Artur Thompsen. Ônus da prova no Novo CPC: do estático ao dinâmico. São Paulo: RT, 2017.

CARRATTA, Antonio. Il principio della non contestazione nel processo civile. Milano: Giuffrè, 1995.

CARVAlHO, Alberto Antonio de Moraes. Praxe Forense ou Directorio Pratico do Processo Civil Brasileiro: tomo 1, Rio de Janeiro: Eduardo e Henrique Laemmert, 1850.

CARVALHO, José Pereira de. Primeiras linhas sobre o processo orfanologico: parte 1. 3.ed. Lisboa: Impressão Regia, 1833.

CARVAlHO, Luiz Antonio da Costa. O Espírito do Código de Processo Civil: comentários e críticas. Rio de Janeiro: Edições Trabalhistas, 1974.

CARVAlHO SANTOS, João Manoel de. Código de Processo Civil Interpretado: volume 3, artigos 180 a 262. Rio de Janeiro/São Paulo: Freitas Bastos, 1940.

CASSIRER, Ernst. A filosofia do Iluminismo. Campinas: UNICAMP, 1997.

CASTRO, Amílcar de. Comentários ao Código de Processo Civil: volume 8, artigos 566 a 747. 2.ed. Rio de Janeiro: Forense, 1976.

CASTRO, Amílcar Augusto. Das execuções de sentença no Estado de Minas Geraes. Belo Horizonte: Imprensa Official, 1928.

CASTRO, Arabela Maria Sampaio de. Da confissão no processo civil. Dissertação (Mestrado em Direito Processual), São Paulo, Faculdade de Direito da USP, 1981.

CASTRO, Arthur Anselmo de. Direito processual civil declaratório: volume 3. Coimbra: Almedina, 1982.

CASTRO, Emmanuel Mendes de. Practica Lusitana. Lisboa: Apud Georgium Rodericum, 1619.

CASTRO, Gabriel Pereira de. Decisiones Supremi Eminentissimique Senatus Portugalliae. Lisboa: Apud Antonium Craesbeeck de Mello, 1674.

CASTRO FILHO, José Olympio de. Abuso do direito no processo civil. Belo Horizonte: Imprensa Oficial, 1955. 
CATAUDELlA, Antonino. Fattispecie. In: Costatino MORTATI; Salvatore PUGLIATTI (dir.). Enciclopedia del Diritto: volume 16. Milano: Giuffrè, 1967, 926-941.

CAVALLARI, Bona Ciaccia. La contestazione nel processo civile: volume 1, la contestazione tra norme e sistema. Milano: Giuffrè, 1992.

La contestazione nel processo civile: volume 2, la non contestazione, caratteri ed effetti. Milano: Giuffrè, 1993.

CEPOLLA, Bartolomeo. Cautele Bartho. Cepol. Lyon: Crespinus, 1535.

CHIOVENDA, Giuseppe. Appendice - Progetto di riforma del procedimento civile. In: . Saggi di Diritto Processuale Civile (1900-1930): volume secondo. Roma: Foro Italiano, 1931, p. 113-96.

Le forme nella difesa giudiziale del diritto. In: Saggi di Diritto Processuale Civile (1900-1930): volume primo. Roma: Foro Italiano, 1930, p. 353-78.

. Instituições de Direito Processual Civil: volume 3, a relação ordinária de cognição (continuação). Trad. J. Guimarães Menegale. Notas de Enrico Tullio Liebman. São Paulo: Saraiva, 1945.

Istituzioni di Diritto Processuale Civile: volume 1, i concetti fondamentali, la dottrina delle azioni. 2.ed. Napoli: Jovene, 1935.

. Principii di diritto processuale civile: le azioni, il processo di cognizione. 3.ed. Napoli: Jovene, 1923.

CICÉRON. Brutus. Ed. e Trad. Jules Martha. 3.ed. Paris: Les Belles Lettres, 1960.

Divisions de l'Art Oratoire - Topiques. Ed. e Trad. Henri Bornecque. Paris: Les Belles Lettres, 1990.

De l'invention. Ed. e Trad. Guy Achard. Paris: Les Belles Lettres, 2018.

. L'Orateur - Du meilleur genre d'orateurs. Ed. e Trad. Henri Bornecque. Paris: Les Belles Lettres, 1921.

CINTRA, Antonio Carlos de Araújo, cf. ARAÚJO CINTRA, Antonio Carlos de

Código civil dos Estados Unidos do Brasil, comentado por Clovis Bevilaqua: volume 1. Rio de Janeiro: Editora Rio, 1979.

Código de Processo Civil: histórico da lei, volume I, tomo I. Brasília: Senado Federal Subsecretaria de Edições Técnicas, 1974.

Código de Processo Civil: histórico da lei, volume I, tomo II. Brasília: Senado Federal Subsecretaria de Edições Técnicas, 1974.

Codigo do Processo do Estado da Bahia Annotado por Eduardo Espinola. Bahia: Typ. Bahiana, 1916. 2 v.. 
Codigo Philippino ou Ordenações e Leis do Reino de Portugal Recopiladas por Mandado d'El-Rey D. Philippe I. 14a edição. ed. Candido Mendes de Almeida. Rio de Janeiro: Typographia do Instituto Philomathico, 1870.

COING, Helmut. Zum Einfluß der Philosophie des Aristoteles auf die Entwicklung des römischen Rechts. Zeitschrift der Savigny-Stiftung für Rechtsgeschichte: Romanistische Abteilung, n. 69 (1), p. 24-59, 1952.

COLLINET, Paul. La procédure par libelle. Paris: Sirey, 1932.

. Les P. Oxy. 1876-1882 et la procédure par libelle avant Justinien. Revue de droit français et étranger, Paris, n. 3, p. 720-25, 1924.

Consolidação das Leis do Processo Civil, commentada pelo Dr. Antonio Joaquim Ribas: volume I. Rio de Janeiro: Dias da Silva Junior, 1879.

CONSOLO, Claudio. Le impugnazioni delle sentenze e dei lodi. 3.ed. Padova: CEDAM, 2012.

Spiegazioni di diritto processuale civile: volume 1, le tutele (di merito, sommarie ed esecutive) e il rapporto giuridico processuale. 10.ed. Torino: G. Giappichelli, 2015.

COOPER, Craig. Forensic oratory. In: Ian WORTHINGTON (ed.). A Companion to Greek Rhetoric. Oxford: Blackwell, 2007.

CORNÉLIUS NEPOS. Oeuvres. Ed. e Trad. Anne-Marie Guillemin. Paris: Les Belles Lettres, 1923.

Corpus Iuris Civilis Iustinianei, cum commentariis Accursii...: Tomus Primus, Digestum Vetus. Lyon: s.e., 1627.

CORRÊA, Fábio Peixinho Gomes. O objeto litigioso no processo civil. São Paulo: Quartier Latin, 2009.

CORTES, Hélio Armond Werneck. Revelia, confissão e transigência: relativamente aos direitos (indisponíveis) em o Código de Processo Civil vigente. Revista dos Tribunais, São Paulo, n. 471, p. 26-36, jan. 1975.

COSTA, Alfredo de Araújo Lopes da: v. LOPES da COSTA, Alfredo de Araújo

COSTA, Eduardo José Fonseca da; Heitor Vitor Mendonça SICA. Legislação processual extravagante. Salvador: Juspodivm, 2016, p. 177-206 (Coleção Repercussões do Novo CPC, volume 9, coordenada por Fredie Didier Jr.).

COSTA, Guilherme Recena. Livre convencimento e standards de prova. In: Camilo ZUFELATO; Flávio Luiz YARSHELL (org.). 40 anos da Teoria Geral do Processo no Brasil: passado, presente e futuro. São Paulo: Malheiros, 2013, p. 356-80.

COSTA, Mário Júlio de: v. ALMEIDA COSTA, Mário Júlio de

COSTA, Moacyr Lobo da: v. LOBO da COSTA, Moacyr 
COSTA CRUZ, Manoel Martins da. Curso Elementar de Pratica do Processo no Civel e no Crime. Revisto por Paulo M. de Lacerda. Rio de Janeiro: Jacintho Ribeiro dos Santos, 1929, 3 v..

COUSIN, Jean. Études sur Quintilien I: contribution à la recherche des sources de l'Institution Oratoire. Amsterdam: P. SCHNIPPERS N. V., 1967.

COUTO e SILVA, Clóvis V.. Comentários ao Código de Processo Civil: volume 11, tomo 1, artigos 890 a 1045. São Paulo: RT, 1977.

. Comentários ao Código de Processo Civil: volume 11, tomo 2, artigos 1046 a 1102. São Paulo: RT, 1982.

A obrigação como processo. Rio de Janeiro: FGV, 2006.

COUTURE, Eduardo Juan. El deber de las partes de decir la verdad. In: Estudios de derecho procesal: tomo 3, el juez, las partes y el proceso. 3.ed. Buenos Aires: Depalma, 1989, p. 233-58.

. Fundamentos del derecho procesal civil. 3.ed. Buenos Aires: Depalma, 1973.

. Proyecto de Código de Procedimiento Civil: con exposición de motivos. Buenos Aires: DePalma, 1945.

. Vocabulario jurídico: con especial referencia al derecho procesal positivo vigente uruguayo. Buenos Aires: Depalma, 1983.

COVELLO, Sergio Carlos. Ação de alimentos. 3.ed. São Paulo: Leud, 1992.

CRADDOCK, Jerry R.. The legislative works of Alfonso X, el Sabio: a critical bibliography. London/ Wolfeboro, NH: Grant \& Cutler, 1986.

CRESCI SOBRINHO, Elicio de. Dever de esclarecimento e complementação no processo civil. Porto Alegre: Sergio Antonio Fabris, 1988.

CRETELLA NETO, José. Dicionário de Processo Civil. Rio de Janeiro: Forense, 1999.

CROOK, John Anthony. Consilium principis: imperial councils and counsellors from Augustan to Diocletian. Cambridge: Cambridge University Press, 1955.

CRUZ, Manoel Martins da Costa: v. COSTA CRUZ, Manoel Martins da

CRUZ e TUCCI, José Rogério. A causa petendi no processo civil. 2.ed. São Paulo: RT, 2001.

. Comentários ao Código de Processo Civil: volume 7, arts. 318 a 368. São Paulo: Saraiva, 2016 (Coleção Comentários ao Código de Processo Civil, coordenada por José Roberto F. GOUVÊA; Luís Guilherme A. BONDIOLI e João Francisco N. da FONSECA).

. Comentários ao Código de Processo Civil: volume 8, artigos 485 a 538. São Paulo: RT, 2016 (Coleção Comentários ao Código de Processo Civil, dirigida por 
Luiz Guilherme e coordenada por Sergio Cruz ARENHART e Daniel MITIDI$\mathrm{ERO})$.

. Repúdio às novas investidas da "jurisprudência defensiva". O Estado de São Paulo, 25 jul. 2018. Texto disponível em: < https://politica.estadao.com.br/blogs/fausto-macedo/repudio-as-novas-investidas-da-jurisprudenciadefensiva/>Acesso em: 18 set. 2018.

; José Roberto dos Santos BEDAQUE (coord). Causa de pedir e pedido no processo civil: questões polêmicas. São Paulo: RT, 2002.

CULLISON, Alan D.. A Review of Hohfeld's Fundamental Legal Concepts. ClevelandMarshall Law Review, Cleveland, n. 16 (3), p. 559-73, 1967.

CUNHA FRANÇA, Feliciano da. Additiones Aureaeque Illustrationes, ad quinque Libros Primae Partis Practicae Lusitanae Emmanuelis Mendes de Castro: volume 1. Lisboa: Ex Typographia Josephi da Costa Coimbra, 1765.

CUNHA, Leonardo Carneiro da. Comentário ao artigo 489. In: Teresa Arruda Alvim WAMBIER et alii (coord.). Breves Comentários ao Novo Código de Processo Civil. São Paulo: RT, 2015, p. 1227-37.

. A Fazenda Pública em juízo. 14.ed. Rio de Janeiro: Forense, 2017.

Damasi summa de ordine judiciario. In: Agathon WUNDERLICH. Anecdota quae processum civilem spectant. Göttingen: Vandenhoeck et Ruprecht, 1841, p. 27-120.

DALL'AGNOL JUNIOR, Antonio Janyr. Comentários ao Código de Processo Civil: volume 3, artigos 154 a 261, dos atos e nulidades processuais. Porto Alegre: LeJur, 1985.

DANTAS, Bruno. Comentário ao art. 341. In: Antonio do Passo CABRAL; Ronaldo CRAMER (coord.). Comentários ao Novo Código de Processo Civil. Rio de Janeiro: Forense, 2015, p. 544.

DAUCHY, Serge. La conception du procès civil dans le Code de procédure de 1806. In: Loïc CADIET; Guy CANIVET (coord.). 1806 - 1976 - 2006 - De la commémoration d'un code à l'autre: 200 ans de procédure civile en France. Paris: Litec, 2006, p.77-89.

DEGENKOLB, Heinrich. Einlassungszwang und Urtheilsnorm. Leipzig: Breitkopf und Härtel, 1877.

DEMARTINI, Anne-Emmanuelle. Les plaidoiries en vers au XIX ${ }^{\mathrm{e}}$ siècle. Francofonia, Bologne, n. 67, p. 49-60, 2014.

DIAS, Maria Berenice. Consignação em pagamento. In: José Carlos Teixeira GIORGIS (org.). Inovações do Código de Processo Civil. Porto Alegre: Livraria do Advogado, 1996, p. 183-96. 
DIAS, Ronaldo Bretas de Carvalho. A constitucionalização do novo Código de Processo Civil. In: Fredie DIDIER JR.; Dierle NUNES; Alexandre FREIRE (coord.). Normas Fundamentais. Salvador: Juspodivm, 2016, p. 59-74 (Coleção Grandes Temas do Novo CPC, volume 8, coordenada por Fredie DIDIER JR.).

Digesta Iustiniani Augusti. Ed. Pietro BONFANTE et alii. Milano: Formis Societatis Editricis Librariae, 1931.

DIDIER JR., Fredie. Curso de Direito Processual Civil: volume 1, introdução ao direito processual civil, parte geral e processo de conhecimento. 17.ed. São Paulo: Juspodivm, 2015.

; Paula Sarno BRAGA; Rafael OLIVEIRA. Curso de Direito Processual Civil: volume 2. 10.ed. Salvador: Juspodivm, 2015.

; Leonardo Carneiro da CUNHA. Curso de Direito Processual Civil: volume 3. 13.ed. Salvador: Juspodivm, 2016.

; __ _ Paula Sarno BRAGA; Rafael Alexandria de OLIVEIRA. Curso de Direito Processual Civil: volume 5. 7.ed. Salvador: Juspodivm, 2017.

; Antonio do Passo CABRAL; Leonardo Carneiro da CUNHA. Para uma nova teoria dos procedimentos especiais: dos procedimentos às técnicas. Salvador: Juspodivm, 2018.

; Pedro Henrique Pedrosa NOGUEIRA. Teoria dos fatos jurídicos processuais. Salvador: Juspodivm, 2011.

DINAMARCO, Cândido Rangel. Das ações típicas. In: . Fundamentos do processo civil moderno; volume 1. 6.ed. São Paulo: Malheiros, 2010, p. 463-94.

. Causa de pedir e ônus de afirmar. In: Fundamentos do Processo Civil Moderno: volume 2. 4.ed. São Paulo: Malheiros, 2001, p. 929-37.

. Direito Processual Civil. São Paulo: José Bushatsky, 1975.

. Execução civil. 7.ed. São Paulo: Malheiros, 2000.

. Execução civil: a execução na teoria geral do direito processual civil. São Paulo: TY, 1973.

. Instituições de Direito Processual Civil: volume 1. 8.ed. São Paulo: Malheiros, 2016.

. Instituições de Direito Processual Civil: volume 2. 7.ed. São Paulo: Malheiros, 2017.

Instituições de Direito Processual Civil: volume 3. 7.ed. São Paulo: Malheiros, 2017.

. Os institutos fundamentais do direito processual. In: . Fundamentos do processo civil moderno: volume 1. 6.ed. São Paulo: Malheiros, 2010, p. 245-98. 
A instrumentalidade do processo. 13.ed.São Paulo: Malheiros, 2008.

Manual dos Juizados Cíveis. 2.ed. São Paulo: Malheiros, 2001.

Ônus de contestar e o efeito da revelia. Revista de Processo (São Paulo), n. 41, p. 185-97, 1986.

Polêmicas do processo civil. In: Cândido Rangel DINAMARCO. Fundamentos do processo civil moderno: volume 1. $6^{\text {a }}$ edição. São Paulo: Malheiros, 2010, vol. I, p. 97-112.

O princípio do contraditório e sua dupla destinação. In: Fundamentos do processo civil moderno: volume 1. 6.ed. São Paulo: Malheiros, 2010, p. 517-28. A Reforma do Código de Processo Civil. 5.ed. São Paulo: Malheiros, 2001. . Vocabulário do Processo Civil. 2.ed. São Paulo: Malheiros, 2014.

; Bruno Vasconcelos Carrilho LOPES. Teoria Geral do Novo Processo Civil. São Paulo: Malheiros, 2016.

DINAMARCO, Pedro da Sillva. Ônus processuais: limites à aplicação das consequências previstas para o seu não-cumprimento. Tese (Doutorado em Direito Processual Civil), São Paulo, Faculdade de Direito da USP, 2007.

DÖLLE, Hans. Rechtsdogmatik und Rechtsvergleichung. Rabels Zeitschrift für ausländisches und internationales Privatrecht, n. 34, 3/4, p. 403-410, 1970.

DOMIT, Otávio Augusto dal Molin. Iura novit curia e causa de pedir. São Paulo: RT, 2016.

DUARTE NAZARETH, Francisco José. Elementos do Processo Civil. 2.ed. Coimbra: Livraria de J. Augusto Orcel, 1863.

DUFOUR, Médéric. Introduction. In: ARISTOTE. Rhétorique: tome premier, livre I. Ed. Médéric Dufour. Paris: Les Belles Lettres, 1932, p. 5-25.

DURANTE, Vincenzo. Onere. In: Bruno PARADISI (dir.). Enciclopedia Giuridica: volume 24, obbligazione-ordine. Roma: Istituto dell'Enciclopedia Italiana Treccani, 2007, p. 1-10.

DUTRA, Pedro. Literatura jurídica no império. 2.ed. Rio de Janeiro: Padma, 2004.

DWORKIN, Ronald. The Model of Rules I. In: IDEM. Taking Rights Seriously. Cambridge: Harvard University Press, 1978.

EID, Elie Pierre. Litisconsórcio unitário: fundamentos, estrutura e regime. São Paulo: RT, 2016.

EKELÖF, Per Olof. Free evaluation of evidence. Studies in Scandinavian Law, Stockholm, n. 8, p. 47-66, 1964. 
ENGISCH, Karl. Einführung in das juristische Denken. 8.ed. Stuttgart/Berlin/Köln: Kohlhammer, 1983.

Logische Studien zur Gesetzanwendung. 3.ed. Heidelberg: Carl Winter, 1963.

ERNOUT, Alfred; Antoine MEILLET. Dictionnaire étymologique de la langue latine: histoire des mots. 3.ed. Paris: Klincksieck, 1951.

FABRÍCIO, Adroaldo Furtado. Comentários ao Código de Processo Civil: volume 8, tomo 3, artigos 890 a 945. 4.ed. Rio de Janeiro: Forense, 1992.

. Justificação teórica dos procedimentos especiais. In: . Ensaios de Direito Processual. Rio de Janeiro: Forense, 2003, p. 33-53.

FALZEA, Angelo. Fatto giuridico. In: Costantino MORTATI; Salvatore PUGLIATTI (dir.). Enciclopedia del Diritto: volume 16. Milano: Giuffrè, 1967, p. 941-50. Il soggetto nel sistema dei fenomeni giuridici. Milano: Giuffrè, 1939.

FARIA, Bento de. Código Commercial Brazileiro Annotado. 2.ed. Rio de Janeiro: Jacintho Ribeiro dos Santos, 1912.

FARIA, Márcio Carvalho. A lealdade processual na prestação jurisdicional: em busca de um modelo de juiz leal. São Paulo: RT, 2017.

FAZZALARI, Elio. Istituzioni di diritto processuale. 8.ed. Padova: CEDAM, 1996.

FERNANDES, Francisco. Dicionário Brasileiro Contemporâneo Ilustrado. 2.ed. Porto Alegre: Globo/Melhoramentos, 1967.

FERRAZ JR., Tércio Sampaio. A ciência do direito. 2.ed. São Paulo: Atlas, 2012. . Função social da dogmática jurídica. $2^{\mathrm{a}}$ edição. São Paulo: Atlas, 2015.

. Teoria da norma jurídica: um modelo pragmático. In: S. FERRAZ (coord.). A norma jurídica. Rio de Janeiro: Freitas Bastos, 1980, p. 7-37.

FERREIRA, Aurélio Buarque de Hollanda. Novo Dicionário da Língua Portuguesa. 2.ed. Rio de Janeiro: Nova Fronteira, 1986.

FERREIRA, José Dias. Código de Processo Civil Annotado: tomo I. Lisboa: Typographia Lisbonense, 1887.

FERREIRA, Pinto. Da resposta do réu. 2.ed. São Paulo: Saraiva, 1987.

FERREIRA, William Santos. Transições paradigmáticas, máxima eficiência e técnicas executivas típicas e atípicas no direito probatório. In: Marcos Félix JOBIM; William Santos FERREIRA. Direito Probatório. Salvador: Juspodivm, 2015, p. 36986 (Coleção Grandes Temas do Novo CPC, coordenada por Fredie Didier Jr., volume 5).

FISCHMANN, Gerson. Comentários ao Código de Processo Civil: volume 14, dos procedimentos especiais, artigos 982 a 1102c. São Paulo: RT, 2000. 
FORMIGA, Armando Soares de Castro. Periodismo jurídico no Brasil do século XIX: história do direito em jornais e revistas. Curitiba: Juruá, 2010.

FOUCAULT, Michel. Les mots et les choses: une archéologie des sciences humaines. Paris: Gallimard, 1966.

FOWLER-MAGERL, Linda. Ordines iudiciarii and libelli de ordine iudiciorum: from the middle of the twelfth to the end of the fifteenth century. Turnout: Brepols, 1994 (Coleção Typologie des sources du moyen âge occidental, volume 63).

FRAGA, Affonso. Instituições do Processo Civil do Brasil: tomo II. São Paulo: Saraiva, 1940.

. Theoria e pratica na execução das sentenças. São Paulo: C. Teixeira \& C., 1922.

FRANÇA, Feliciano da Cunha: v. CUNHA FRANÇA, Feliciano da

FRANCO, João Nascimento. Ação renovatória. São Paulo: Malheiros, 1994.

. Manual prático da ação revisional. São Paulo: Malheiros, 1992.

FREDERICO MARQUES, José. Instituições de Direito Processual Civil: volume I. Rio de Janeiro: Forense, 1958.

. Instituições de Direito Processual Civil: volume 2. Rio de Janeiro: Forense, 1958.

. Instituições de Direito Processual Civil: volume 3. Rio de Janeiro: Forense, 1959.

. Manual de Direito Processual Civil: volume 1, teoria geral do processo civil. 4.ed.

São Paulo: Saraiva, 1974.

Regulamento No. 737 de 1850. O Estado de São Paulo, 17 de agosto de 1958.

FREIRE, Paschoal José de Mello: v. MELLO FREIRE, Paschoal José de

FREITAS, José Lebre de: v. LEBRE de FREITAS, José

FRIEDBERG, Emil (ed.). Quinque Compilationes Antiquae, necnon Collectio Canonum Lipsiensis. Leipzig: Bernhard Tauchnitz, 1882.

FRUS, Giorgio. Note sull'onere del convenuto di 'prendere posizione' nel processo del lavoro. Rivista Trimestrale di Diritto e Procedura Civile, Milano, n. 45 (1), p. 63103, mar. 1991

Fuero juzgo en latin y castellano, cotejado con los mas antiguos y preciosos códices, por la Real Academia Española. Madrid: Ibarra, 1815.

GADAMER, Hans-Georg. On the Circle of Understanding. In: John M. CONNOLY; Thomas KEUTNER; Hans-Georg GADAMER (org.). Hermeneutics versus science? Three German views. Notre Dame: University of Notre Dame Press, 1988, p. $68-78$ 
Truth and Method. 2.ed. Trad. Joel Weinsheiner e Donald G. Marshall. New York: Continuum, 1989.

GAGARIN, Michael. Background and Origins: oratory and rhetoric before the sophists. In: Ian WORTHINGTON (ed.). A Companion to Greek Rhetoric. Oxford: Blackwell, 2007, p. 27-36.

GAIUS. Institutes. Ed. e Trad. Julien Reinach. Paris: Les Belles Lettres, 2003.

GAMA, Affonso Dionysio. Inventarios e partilhas. 2.ed. São Paulo: Saraiva, 1926.

GAMA BARROS, Henrique da. História da Administração Pública em Portugal nos séculos XII a XV. 2.ed. dirigida por Torquato de Sousa Soares. Lisboa, Sá da Costa, $1945-54,11 \mathrm{v} .$.

GAMMA, Antonio da. Decisionum Supremi Senatus Lusitaniae. Antwerpen: Apud Joannem Baptistam Verussen, 1683.

GERALDES, António Santos Abrantes. Temas da Reforma do Processo Civil: volume 1. 2.ed. Coimbra: Almedina, 2010.

; Paulo PIMENTA; Luís Filipe Pires de SOUSA. Código de Processo Civil Anotado: volume 1, parte geral e processo de declaração, artigos $1^{\circ}$ a $702^{\circ}$. Coimbra: Almedina, 2018.

GERI, Lina Bigliazzi. Oneri reali e obbligazioni propter rem. Milano: Giuffrè, 1984 (Coleção Trattato di diritto civile e commerciale, volume 11, 3, dirigida por L. MENGONI).

GIANESINI, Rita. Da revelia no processo civil brasileiro. São Paulo: RT, 1997.

GLARE, Peter G. W. (ed.). Oxford Latin Dictionary. Oxford: Clarendon Press, 1982.

GOLDSCHMIDT, James. Der Prozess als Rechtslage: eine Kritik des prozessualen Denkens. Berlin/Heidelberg: Springer, 1925.

Zivilprozessrecht. Berlin/Heidelberg: Springer, 1929.

GOMES, Alexandre Caetano. Manual Pratico, Juicial, Civel, e Criminal. Lisboa: Na Officina de Caetano Ferreira da Costa, 1766.

GOMES da SILVA, Nuno J. Espinosa. História do direito português: fontes de direito. 3.ed. Lisboa: Calouste Gulbenkian, 2000.

GOUVEA, Lúcio Soares Teixeira de. Código do Processo Criminal: proposta do governo apresentada em sessão de 20 de maio de 1829. In: A. P. PINTO (ed.). Annaes do Paralemento Brazileiro: Camara dos Srs. Deputados, Quarto Anno da Primeira Legislatura, sessão de 1829. Rio de Janeiro: Typographia H. J. Pinto, 1877, p. 111-29. 
Gratiae Aretini de iudiciario ordine. In: Pillii, Tancredi, Gratiae libri de iudiciorum ordine. Ed. Friedrich Bergmann. Göttingen: Vandenhoeck et Ruprecht, 1842, p. 317-384.

GRAU, Eros. Por que tenho medo dos juízes: a interpretação/aplicação do direito e os princípios. 6.ed. São Paulo: Malheiros, 2014.

GRECO, Leonardo. Instituições de Processo Civil: volume 1, introdução ao direito processual civil. 5.ed. Rio de Janeiro: Forense, 2015.

. Instituições de Processo Civil: volume 2, processo de conhecimento. 3.ed. Rio de Janeiro: Forense, 2015.

. O processo de execução: volume 2. Rio de Janeiro/São Paulo: Renovar, 2001.

GRENFELL, Bernard Pyne; Arthur S. HUNT; Harold Idris BELL. The Oxyrrhynchus Papyri: volume 16. London: Egypt Exploration Society, 1924.

GRINOVER, Ada Pellegrini. Ensaio sobre a processualidade: fundamentos para uma nova teoria geral do processo. Brasília: Gazeta Jurídica, 2016.

. Os princípios constitucionais e o Código de Processo Civil. São Paulo: José Bushatsky, 1975.

GUSMÃO, Manoel Aureliano de. Processo Civil e Commercial: volume 1. São Paulo: Saraiva, 1921.

. Processo Civil e Commercial: volume 1. São Paulo: Saraiva, 1924.

GUSMÃO, Helvecio de. Código do Processo Civil e Commercial para o Districto Federal: mandado executar pel Dec. n. 16.752, de 31 de dezembro de 1924, annotado com a Doutrina, as legislações federal e estadual e com a Jurisprudência dos Tribunaes. Rio de Janeiro: Jacyntho Ribeiro dos Santos, 1931.

HÄBERLE, Peter. Hermenêutica constitucional: a sociedade aberta dos intérpretes da Constituição, contribuição para a interpretação pluralista e 'procedimental' da Constituição. Trad. Gilmar Ferreira Mendes. Porto Alegre: Sergio Antonio Fabris, 1997.

HARRIS, Roy. Saussure and his interpreters. 2.ed. Edinburgh: Edinburgh University Press, 2003.

HART, Herbert Lionel Adolphus. Bentham on Legal Powers. Yale Law Journal, New Haven, n. 81, p. 799-822, 1971-72.

. HART. The Concept of Law. 3.ed. Oxford: Oxford University Press, 2012.

HAWHEE, Debra. Bodily Arts: rhetoric and athletics in Ancient Greece. Austin: University of Texas Press, 2004.

HECK, Philipp. Begriffsbildung und Interessenjurisprudenz. In: IDEM: Das Problem der Rechtsgewinnung - Gesetzauslegung und Interessenjurisprudenz - 
Begriffsbildung und Interessenjurisprudenz. Ed. Roland Dubischar. Bad Homburg vor der Höhe/Berlin/Zürich: Gehlen, 1968, p. 142-212.

Gesetzauslegung und Begriffsjurisprudenz. In: IDEM. Das Problem der Rechtsgewinnung - Gesetzauslegung und Interessenjurisprudenz Begriffsbildung und Interessenjurisprudenz. Ed. Roland Dubischar. Bad Homburg vor der Höhe/Berlin/Zürich: Gehlen, 1968, p. 46-141.

HELLWIG, Konrad. Lehrbuch des deutschen Zivilprozessrechts: Band 2. Leipzig: A. Deichert, 1907.

HENNING, Fernando Alberto Corrêa. Ação concreta: relendo Wach e Chiovenda. Porto Alegre: Sergio Antonio Fabris, 2000.

HERCULANO, Alexandre. História de Portugal: desde o começo da moarchia até o fim do reinado de Affonso III. 8.ed. Lisboa/Rio de Janeio: Bertrand/Paulo de Azevedo, s/d, 8 v..

(ed.). Portugaliae Monumenta Historica: tomo II, leges et consuetudines. Lisboa: Typis Academicis, 1856.

HESPANHA, António Manuel. O Direito dos Letrados no Império Português. Florianópolis: Fundação Boiteux, 2006.

HEUMANN, Hermann Gottlieb; Emil SECKEL. Heumanns Handlexikon zu den Quellen des römischen Rechts. 9.ed. Jena: Gustav Fischer, 1926.

HOBSBAWM, Eric John Ernest. A era das revoluções. Trad. Maria Tereza Lopes Teixeira e Marcos Penchel. Rio de Janeiro: Paz e Terra, 1991.

HOHFELD, Wesley Northcomb. Fundamental Legal Conceptions as Applied in Judicial Reasoning. Yale Law Journal, n. 26, p. 710-70.

. Fundamental Legal Conceptions as Applied in Judicial Reasoning and Other Legal Essays. Ed. Walter Wheeler Cook. New Haven: Yale University Press, 1923.

. Some Fundamental Legal Conceptions as Applied in Judicial Reasoning. Yale Law Journal, New Haven, n. 23, p. 16-59, 1913.

HORN, Christoph; Dieter SCHÖNECKER (ed.). Groundwork for the Metaphysics of Morals. Berlin/New Yorl: De Gruyter, 2006.

HOUAISS, Antonio; Mauro de Salles VILLAR; Francisco Manoel de MELLO FRANCO. Dicionário Houaiss da Língua Portuguesa. Rio de Janeiro: Objetiva, 2001.

Incerti auctoris ordo iudiciorum (Ulpianus de edendo). Ed. Gustav Haenel. Leipzig: Sumptibus I. C. Hinrichsii, 1838.

IRTI, Natalino. Due saggi sul dovere giuridico: obbligo-onere. Napoli: Jovene, 1973. 
JAKOBSON, Roman. Linguística e poética. In: IDEM. Linguística e Comunicação. 19.ed. Trad. Izidoro Blikstein e José Paulo Paes. São Paulo: Cultrix, 2003, p. 11861.

JAUERNIG, Othmar; Burkhard HESS. Zivilprozessrecht: ein Studienbuch. 30.ed. München: C. H. Beck, 2011.

JOUSSE, Daniel. Nouveau Commentaire sur L'Ordonnance Civile du mois d'avril 1667: tome premier. Paris: Debure, 1769.

JUNQUEIRA de AZEVEDO, Antonio. Negócio jurídico e declaração negocial. São Paulo, 1986. Tese (Titular em Direito Civil). Faculdade de Direito, Universidade de São Paulo. . Negócio jurídico: existência, validade e eficácia. 4.ed. São Paulo: Saraiva, 2007.

KANT, Immanuel. Fondements de la métaphysique des moeurs. Trad. Victor Delbos. Poitiers: Delagrave, 1979.

. Grundlegung zur Metaphysik der Sitten. In: Kritik der praktischen Vernunft - Grundlegung zur Metaphysik der Sitten. 21.ed. Berlin: Suhrkamp, 2014, p. 7-102 (Coleção Immanuel Kant - Werkausgabe, volume 7, editada por Wilhelm Weischedel).

Untersuchung über die Deutlichkeit der Grundsätze der natürlichen Theologie und der Moral. In: - Vorkritische Schriften bis 1768 - 2. 11.ed. Berlin: Suhrkamp, 2012, p. 739-73 (Coleção Immanuel Kant - Werkausgabe, volume 2, editada por W. WEISCHEDEL).

KASER, Max; HACKL, Karl. Das römische Zivilprozessrecht [1966]. 2.ed. München: C.H. Beck, 1996.

KAULBACH, Friedrich. Immanuel Kants 'Grundlegung zur Metaphysik der Sitten. 2.ed. Darmstadt: Wissenschaftliche Buchgesellschaft, 1996.

KELSEN, Hans. Causality and Retribution. Philosophy of Science, Chicago, n. 8 (4), p. 533-56.

KENNEDY, George Alexander. A New History of Classical Rhetoric. Princeton: Princeton University Press, 1994.

The Earliest Rhetorical Handbooks. The American Journal of Philology, n. 80 (2), p. 169-78, 1959.

KERESZTES, Paul. Tertullian's Apologeticus: a historical and literary study. Latomus, Bruxelles, n. 25 (1), p. 124-33, 1966.

KLEIN, Franz. Pro Futuro: Betrachtungen über Probleme der Civilprozessreform in Oesterreich. Leipzig/Vienna: Franz Deuticke, 1981.

KNIJNIK, Danilo. Os standards do convencimento judicial: paradigmas para o seu possível controle. Revista Forense, Rio de Janeiro, n. 353, p. 15-52, jan.-fev. 2001 
KOCHEM, Ronaldo. Da contestação no novo Código de Processo Civil de 2015: aspectos relevantes. In: Lucas Buril de MACEDO; Ravi PEIXOTO; Alexandre FREIRE (org.). Procedimento Comum. 2.ed. Salvador: Juspodivm, 2016, p. 206-223 (Coleção Novo CPC: doutrina selecionada, volume 2, coordenada por Fredie DIDIER $\mathrm{JR})$.

KOERNER, Ernst Frideryk Konrad. Ferdinand de Saussure: génesis y evolución de su pensamiento en el marco de la lingüística occidental, contribución a la historia y a la teoría lingüística. Trad. Graciela García Montaño. Madrid: Gredos, 1982.

KOHLER, Joseph. Der Prozess als Rechtsverhältnis: Prolegomena zu einem System des Zivilprozesses. Mannheim: J. Bensheimer, 1888.

KOLLER, Hermann. Die dihäretische Methode. Glotta, 39,1/2, 1961, p. 6-24

KUNKEL, Wolfgang. Herkunft und soziale Stellung der römischen Juristen. Weimar: Hermann Böhlaus Nachfolger, 1952.

LAMY, Eduardo de Avelar; Pedro Henrique RESCHKE. Comentário ao art. 80. In: Antonio do Passo CABRAL; Ronaldo CRAMER (coord.). Comentários ao Novo Código de Processo Civil. Rio de Janeiro: Forense, 2015, p. 145-47.

LANGE, Hermann. Römisches Recht im Mittelater: Band I, Die Glossatoren. München: Beck, 1997.

LARENZ, Karl. Metodologia da Ciência do Direito. 6.ed. Trad. José Lamego. Lisboa: Calouste Gulbenkian, 2012.

LAUSBERG, Heinrich. Elementos de Retórica Literária. 6.ed. Trad. R. M. Rosado Fernandes. Lisboa: Calouste Gulbenkian, 2011.

LEBRE de FREITAS, José. A acção declarativa comum: à luz do Código revisto. Coimbra: Coimbra Editora, 2001.

A ação declarativa comum: à luz do Código de Processo Civil de 2013. 4.ed. Coimbra: Gest Legal, 2017. A confissão no direito probatório. Coimbra: Coimbra, 1991.

; Isabel ALEXANDRE. Código de Processo Civil Anotado: volume 2, artigos $362^{\circ}$ a 626․ 4.ed. Coimbra: Almedina, 2019.

Leis Extravagantes e Repertório das Ordenações de Duarte Nunes do Lião. Lisboa: Calouste Gulbenkian, 1987.

LEITÃO, Arthur de Freitas. Notas ao Processo Civil e Commercial: Regulamento n. 737, de 1850. 2.ed. São Paulo: C. Teixeira \& Cia, 1928.

LENEL, Otto. Palingenesia iuris civilis: volume 1. Leipzig: Bernhard Tauchnitz, 1889.

LENT, Friedrich. Obblighi e oneri nel processo civile. Trad. Marco De Stefano. Rivista di Diritto Processuale, Padova, n. 9 (1), p. 150-58, 1954. 
LEIPOLD, Dieter. Prozessförderungspflicht der Parteien und richterliche Verantwortung. Zeitschrift für Zivilprozess, n. 93(3), p. 237-65, ago. 1980.

LEONEL, Ricardo de Barros. Tutela jurisdicional diferenciada. São Paulo: RT, 2010.

Lettres de Pline le Jeune suivies du Panégyrique de Trajan. Paris: Ernest Flammarion, s/d..

LEVI, Giulio. Fatto e diritto. Milano: Giuffrè, 2002.

LÉVY-BRUHL, Henri. Recherches sur les actions de la loi. Paris: Sirey, 1960.

LIDDELL, Henry G.; Robert SCOTT; Henry Stuart JONES. A Greek-English Lexicon: volume 1. 9.ed. Oxford: The Clarendon Press, 1948.

LIEBMAN, Enrico Tullio. Embargos do executado: oposições de mérito no processo de execução. 2.ed. Tradução de J. Guimarães Menegale. São Paulo: Saraiva, 1968.

. Il nuovo 'Codigo de processo civil' brasiliano. In: E. T. LIEBMAN. Problemi del processo civile. Milano: Morano, 1962, p. 483-89.

. L'opera scientifica di James Goldschmidt e la teoria del rapporto processuale. In: IDEM. Problemi del processo civile. Napoli: Morano, 1962, p. 132-46.

. Proposte per una riforma del processo civile di cognizione. Padova: CEDAM, 1978.

LIMA, Alcides de Mendonça: v. MENDONÇA LIMA, Alcides de

LIMA, Herotides da Silva. Código de Processo Civil Brasileiro: volume I, arts. 1 a 297. São Paulo: Saraiva, 1940.

LISBOA, Celso Anicet. A nova Lei de Locações sob o enfoque processual. Rio de Janeiro: Forense, 1992.

LITEWSKI, Wieslaw. Der römisch-kanonische Zivilprozess nach dem älteren ordines iudiciarii. Krákow: Jagiellonian University Press, 1999, 2 v.

LOBÃO, Manoel de Almeida e Sousa de. Segundas linhas sobre o processo civil, ou antes addições às primeiras do Bacharel Joaquim José Caetano Pereira e Sousa: parte primeira [1817]. Lisboa: Imprensa Nacional, 1868.

. Tractado pratico compendiario de todas as acções summarias, sua indole, e natureza em geral, e em especial. Lisboa: Imprensa Nacional, 1842.

LÔBO, Paulo. Direito Civil: parte geral. 6.ed. São Paulo: Saraiva, 2017.

LOBO da COSTA, Moacyr. Assistência. São Paulo: Saraiva, 1968.

Breve Notícia Histórica do Direito Processual Civil Brasileiro e de sua Literatura. São Paulo: RT/Edusp, 1970.

. Confissão e reconhecimento do pedido. São Paulo: Saraiva, 1983. 
Pereira e Sousa e o direito processual. Revista de Processo (São Paulo), n. 26, p. 132-39, abr./jun. 1982.

LOPES, Bruno Vasconcelos Carrilho. Comentários ao Código de Processo Civil: volume 2, arts. 70 a 118. São Paulo: Saraiva, 2017 (Coleção Comentários ao Código de Processo Civil, coordenada por José Roberto F. GOUVÊA; Luís Guilherme A. BONDIOLI e João Francisco N. da FONSECA).

LOPES, João Batista. O depoimento pessoal e o interrogatório livre no processo civil brasileiro e estrangeiro. Revista de Processo, São Paulo, n. 13, p. 87-108, jan.mar. 1979.

; Maria Elizabeth de Castro LOPES. Ampla defesa na execução civil. In: José Manoel de ARRUDA ALVIM et alii (coord.). Execução Civil e Temas Afins: do CPC/1972 ao Novo CPC, estudos em homenagem ao Professor Araken de Assis. São Paulo: RT, 2014, p. 570-76.

LOPES, José Reinaldo de Lima. O Direito na História: lições introdutórias. 5.ed. São Paulo: Atlas, 2014.

. A formação do direito comercial brasileiro: a criação dos Tribunais de Comércio do Império. Cadernos Direito GV, Rio de Janeiro, n. 5 (6), p. 7-70, 2007.

. História da Justiça e do Processo no Brasil do Século XIX. Curitiba: Juruá, 2017.

LOPES da COSTA, Alfredo de Araújo. Da citação no processo civil: volume 1. Belo Horizonte: Imprensa Official do Estado de Minas Geraes, 1927.

. Direito Processual Civil Brasileiro (Código de 1939): volume 2. 2.ed. Rio de Janeiro: José Konfino, 1947.

LUMIA, Giuseppe. Lineamenti di teoria e ideologia del diritto. 2.ed. Milano: Giuffrè, 1978.

. Teoria da Relação Jurídica. Trad. Alcides Tomasetti Jr. Mimeografado.

LÜNIG, Johann Christian (ed.). Codex Augusteus oder neuvermehrtes Corpus Juris Saxonici. Leipzig: Johann Friedrich Gleditschens seel. Sohn, 1724.

MACEDO, Antonio de Sousa de. Decisiones Supremi Senatus Justitiae Lusitaniae. Coimbra: Apud Ludovicum Seco Ferreyra, 1734.

MACHADO, Diogo Barbosa. Bibliotheca Lusitana: histórica, crítica e cronológica, tomo III. Lisboa: Ignacio Rodrigues, 1752.

MACHADO, Marcelo Pacheco. Comentários ao Código de Processo Civil: volume 13, artigos 674 a 718, dos embargos de terceiro até da restauração de autos. São Paulo: Saraiva, 2017, (Coleção Comentários ao Código de Processo Civil, coordenada por José Roberto F. Gouvêa, Luís Guilherme A. Bondioli e João Francisco N. da Fonseca). 
MAIA, José Antonio da Silva. Projecto de Lei da Forma do Processo Civil nos Juízos de Primeira Instância, ou Primeira Parte do Código do Processo Civil: offerecido à Camara dos senhores deputados na sessão de 1828. Rio de Janeiro: Typographia Imperial e Nacional, 1829.

MAIORCA, Carlo. Fatto giuridico - Fattispecie. In: Antonio AZARA; Ernesto EULA (dir.). Novissimo Digesto Italiano: volume 7. Torino: UTET, 1961, p. 111-33.

MALATESTA, Niccolò Framarino dei. Lógica de las pruebas en materia criminal: volume 1. 2.ed. Trad. de Simón Carrejo. Bogotá: Temis, 1978.

MARCATO, Antonio Carlos. Ação de consignação em pagamento. 6.ed. São Paulo: Malheiros, 2001.

O processo monitório brasileiro. São Paulo: Malheiros, 1998.

MARINONI, Luiz Guilherme. Precedentes obrigatórios. 4.ed. São Paulo: RT, 2016.

. Técnica processual e tutela dos direitos. 3.ed. São Paulo: RT, 2010.

Da teoria da relação jurídica processual ao processo civil do Estado constitucional. In: Fredie DIDIER JR; Eduardo JORDÃO (coord.). Teoria do Processo: panorama doutrinário mundial. Salvador: JusPodivm, 2008, p. 541-74.

; Sergio Cruz ARENHART; Daniel MITIDIERO. Novo Código de Processo Civil Comentado. 2.ed. São Paulo: RT, 2016.

; ___ ____ Novo Curso de Processo Civil: volume 2, tutela dos direitos mediante procedimento comum. São Paulo: RT, 2015.

; ___ ____ Novo Curso de Processo Civil: volume 3, tutela dos direitos mediante procedimentos diferenciados. São Paulo: RT, 2015.

; __ Comentários ao Código de Processo Civil: volume 4, artigos 294 a 333. São Paulo: RT, 2016 (Coleção Comentários ao Código de Processo Civil, dirigida por Luiz Guilherme Marinoni e coordenada por Sérgio Cruz Arenhart e Daniel Mitidiero).

; __ Comentários ao Código de Processo Civil: volume 6, artigos 369 a 380. São Paulo: RT, 2016, p. 298-300 (Coleção Comentários ao Código de Processo Civil, dirigida por Luiz Guilherme Marinoni e coordenada por Sérgio Cruz Arenhart e Daniel Mitidiero).

; ___ Prova e convicção. 3.ed. São Paulo: RT, 2015.

; Daniel MITIDIERO. Ação Rescisória: do juízo rescindente ao juízo rescisório. São Paulo: RT, 2017.

;___. Comentários ao Código de Processo Civil: volume 16, artigos 976 a 1044. São Paulo: RT, 2016.

; __ O P Projeto do CPC: críticas e propostas. São Paulo: RT, 2010. 
MARMITT, Arnaldo. Consignação em pagamento. Rio de Janeiro: Aide, 1990.

MARNIER, Ange-Ignace. Établissements et coutumes, assises et arrêts de l'Échiquier de Normandie, au XIII ${ }^{e}$ siècle: 1207-1245, d'après le manuscrit F.2 de la Bibliothèque Sainte-Geneviève. Paris: Techener, 1839.

MARQUES, José Frederico: v. FREDERICO MARQUES, José

MARTINS, Antonio Carlos G.. Dos embargos de segunda fase: aspectos relevantes. São Paulo: Leud, 2000.

MARTINS, Octavio. Inventarios e partilhas. Uberaba: Livraria Jardim, 1925.

MARTINS, Pedro Batista. $O$ abuso do direito e o ato ilícito. 2.ed. Rio de Janeiro/São Paulo: Freitas Bastos, 1941.

Comentários ao Código de Processo Civil: volume 2, artigos 133 a 215. Rio de Janeiro: Forense, 1941.

MARTINS-COSTA, Judith. A boa-fé no direito privado: critérios para a sua aplicação. São Paulo: Marcial Pons, 2015.

MASPERO, Jean. Papyrus Grecs d'Époque Byzantine: tome troisième, ${ }^{\text {os }}$ 67279-67359. Le Caire: Imprimerie de l'Institut Français d'Archéologie Orientale, 1916 (Coleção Catalogue Général des Antiquités Égyptiennes du Musée du Caire, sob a organização do Service des Antiquités de l'Égypte).

MATTIROLO, Luigi. Trattato di Diritto Giudiziario Civile Italiano: volume 2. 5.ed. Torino: UTET, 1933.

MATTOSO, José; Armindo de SOUSA. A monarquia feudal: 1096-1480. Lisboa: Estampa, 1997 (Coleção História de Portugal, dirigida por José Mattoso, volume 2).

MAXIMILIANO, Carlos. Direito das sucessões: volume 3. 2.ed. Rio de Janeiro/São Paulo: Freitas Bastos, 1943.

. Hermenêutica e Aplicação do Direito. 7.ed. Rio de Janeiro/São Paulo: Freitas Bastos, 1961.

MAZZACANE, Enio. La litis contestatio nel processo civile canonico. Napoli: Jovene, 1954.

MAZZINI, Giuseppe. Doveri dell'uomo. Firenze: Vallecchi, 1921.

MEDICUS, Dieter. Allgemeiner Teil des BGB. 9.ed. Heidelberg: C. F. Müller, 2006.

MEDINA, José Miguel Garcia. Direito Processual Civil Moderno. São Paulo: RT, 2015.

MELLO, Felipe Viana de. O reconhecimento da aplicabilidade da teoria do ônus dinâmico no processo civil brasileiro. Revista dialética de direito processual. São Paulo, n. 139, p. 32-43, out. 2014. 
MELLO, Marcos Bernardes de. Breves considerações acerca da crítica de Jan Peder Schmidt à concepção de Pontes de Miranda dos planos do mundo jurídico. Revista Fórum de Direito Civil, Belo Horizonte, n. 12, p. 189-95, maio/ago. 2016.

. Teoria do Fato Jurídico: plano da eficácia. 9.ed. São Paulo: Saraiva, 2014.

. Teoria do Fato Jurídico: plano da existência. 20.ed. São Paulo: Saraiva, 2014.

MELLO FREIRE, Paschoal José de. Instituiçoens de Direito Civil Luzitano tanto publico, como particular: livro segundo, do direito das pessoas. Trad. Francisco Pereira Freire. Pernambuco: Typ. de Pinheiro \& Faria, 1834.

. Instituiçoens de Direito Civil Luzitano tanto publico, como particular: livro terceiro, do direito das cousas. s/l: s/e, s/d.

. Instituiçoens de Direito Civil Luzitano tanto publico, como particular [contém os títulos X a XIV do livro III e os títulos I a V do livro IV]. Trad. Manoel Correa Lima. Pernambuco: Typographia de Santos \& Companhia, 1839.

Instituiçoens de Direito Civil Luzitano tanto publico, como particular: livro quarto, das obrigações e acções [contém os títulos VI a seguintes, correspondentes às "acções"]. Trad. Jozé Nicolau Regueira Costa. Pernambuco: Typ. Fidedigna de J. N. de Mello, s/d.

- Institutiones iuris civilis lusitani cum publici tum privati: liber IV, de obligationibus et actionibus [1794]. Coimbra: Ex typis academicis, 1853.

MENDES JUNIOR, João. Artigos - articulados [1 ${ }^{\mathrm{a}}$ parte]. Revista da Faculdade de Direito de São Paulo, São Paulo, n. 4, p. 299-311, 1896.

Artigos - articulados [2 ${ }^{\mathrm{a}}$ parte]. Revista da Faculdade de Direito de São Paulo, São Paulo, n. 7, p. 81-99, 1899.

Direito Judiciario Brazileiro. São Paulo: Typ. Hennies Irmãos, 1910.

. Direito Judiciario Brasileiro. 2.ed. Rio de Janeiro: Typographia Baptista de Souza, 1918.

MENDONÇA LIMA, Alcides de. Dicionário do Código de Processo Civil Brasileiro. 2.ed. São Paulo: RT, 1994.

Direito Processual Civil. São Paulo: José Bushatsky, 1977.

. A nova sistemática das exceções. In: . Direito Processual Civil. São Paulo: José Bushatsky, 1977, p. 43-76.

. A nova sistemática dos embargos. Revista dos Tribunais, São Paulo, n. 474, p. 1120, abr. 1975.

A primazia do Código de Processo Civil e Comercial do Rio Grande do Sul. In: . Direito Processual Civil. São Paulo: José Bushatsky, 1977, p. 301-07. 
Probidade processual e finalidade do processo. Uberaba: Vitória, 1978.

MESQUITA, Abaeté de Paula. Ônus da impugnação específica é ferramenta importante. Conjur, 11 mai. 2006. Disponível em: < https://www.conjur.com.br/2006-mai11/onus_impugnacao_especifica_ferramenta_importante> Acesso em: 20 set. 2018.

MICHELI, Gian Antonio. La carga de la prueba. Bogotá: Temis, 1989.

L'onere della prova. Padova: CEDAM, 1966.

MIGLIORINI, Bruno; Aldo DURO. Prontuario etimologico della lingua italiana. 2.ed. Torino: G. B. Paravia \& Comp., 1953.

MIRAGEM, Bruno. Abuso do Direito: ilicitude objetiva e limite ao exercício de prerrogativas jurídicas no direito privado. 2.ed. São Paulo: RT, 2013.

MIRANDA, Francisco Cavalcanti Pontes de: v. PONTES DE MIRANDA, Francisco Cavalcanti

MITIDIERO, Daniel. Colaboração no processo civil. 3.ed. São Paulo: RT, 2015.

MONATERI, Pier Giuseppe. Fattispecie. In: Digesto delle Discipline Civilistiche: sezione civile, volume 8. Torino: UTET, 2007, p. 223-27.

MONIZ de ARAGÃO, Egas Dirceu. Comentários ao Código de Processo Civil: volume 2, artigos 154 a 269. 10.ed. Rio de Janeiro: Forense, 2004.

MONTEIRO, João. Programma do Curso de Processo Civil: II volume, do processo ordinario, $1^{a}$ parte. São Paulo: Companhia Industrial de São Paulo, 1900.

MORAES SILVA, Antonio. Diccionario da Lingua Portugueza: tomo primeiro. Lisboa: Typographia Lacerdina, 1813

MOREIRA, José Carlos Barbosa: v. BARBOSA MOREIRA, José Carlos

MOURA, Mario de Assis. Formulario Forense Civel e Commercial: de accordo com a legislação processual do paiz. São Paulo: Saraiva. 1932.

MOTA PINTO, Carlos Alberto da. Cessão da Posição Contratual. Coimbra: Almedina, 2003. Teoria Geral do Direito Civil. 3.ed. Coimbra: Almedina, 1985.

MUSIELAK, Hans-Joachim. Grundkurs ZPO. 6.ed. München: C.H. Beck, 2002.

NADEAU, Ray. Classical Systems of Stases in Greek: Hermagoras to Hermogenes. Greek, Roman, and Byzantine Studies, Durham, n. 2 (1), p. 53-71, 1959.

NAVARro, Antonio Caetano Seve. Prática do Processo Civil Comparado com o Comercial. Recife: Universal, 1868. 
NAVES, Cândido. Comentários ao Código de Processo Civil: volume 6, artigos 465 a 523. Rio de Janeiro: Forense, 1941.

NAZARETH, Francisco José Duarte: v. DUARTE NAZARETH, Francisco José

NERO, João Alberto Schutzer del. Considerações sobre a eficácia do registro, efetuado em registro público material e territorialmente competente, de negócios jurídicos de obrigação e de certos negócios jurídicos de disposição. Revista de direito mercantil, industrial, econômico e financeiro (São Paulo), n. 166-67, p. 219-71, $2013-$ 14.

NERY JUNIOR, Nelson. Princípios do Processo na Constituição Federal: processo civil, pena e administrativo. 11.ed. São Paulo: RT, 2013

; Rosa Maria de Andrade NERY. Comentários ao Código de Processo Civil. São Paulo: RT, 2015.

NETO, Abílio. Código de Processo Civil Anotado. 5.ed. Lisboa: Petrony, 1983

NEVES, Celso. Estrutura fundamental do processo civil: tutela jurídica processual, ação, processo e procedimento. 2.ed. Rio de Janeiro: Forense, 1997.

NEVES, Daniel Amorim Assumpção. Manual de Direito Processual Civil: volume único. 8.ed. Salvador: Juspodivm, 2016.

NOGUEIRA, José Luiz de Almeida. A Academia de São Paulo: tradições e reminiscências, estudantes, estudantões, estudantadas, quinta série. São Paulo: Vanorden, 1908.

NORMAND, Claudine. Saussure. 2.ed. Paris: Les Belles Lettres, 2004.

NÖRR, Knut Wolfgang. Die Literatur zum gemeinen Zivilprozess. In: Helmut COING (ed.). Handbuch der Quellen und Literatur der neuren europäischen Privatrechtsgeschichte: Band I, Mittelalter. München: C.H. Beck, 1973, p. 383397.

OLIVEIRA, Aldemir. A contestação do réu no processo ordinário: defesas diretas e indiretas contra o processo e sua área de circunfluência. São Paulo: Julex, 1988.

OLIVEIRA FILHO, Candido de. Pratica Civil: formulario dos actos mais importantes do Codigo Civil. Rio de Janeiro: Livraria Editora Conselheiro Candido de Oliveira, 1927-44, 16 v..

OLIVEIRA, Carlos Alberto Alvaro de: v. ALVARO de OLIVEIRA, Carlos Alberto

OLIVER, D. T.. Roman Law as Illustrated in Pliny's Letters. The Cambridge Law Journal, Cambridge, n. 4 (2), p. 153-63, 1931.

Ordenações Afonsinas: livro III. Lisboa: Calouste Gulbenkian, 1984.

Ordenações Manuelinas: livro III. Lisboa: Calouste Gulbenkian, 1984. 
Ordo judiciarius. In: F. KUNSTMANN. Ueber den ältesten Ordo judiciarius. Kritische Ueberschau der deutschen Gesetzgebung und Rechtswissenschaft, München, n. 2, 1855, p. 10-29.

Der ordo iudiciarius des Aegidius de Fuscarariis. In: Ludwig Wahrmund (ed.). Quellen zur Geschichte der römisch-kanonischen Processes im Mittelalter: III. Band. I. Heft (Halbband). Innsbruck: Verlag der Wagnerschen K. K. UniversitätsBuchhandlung, 1916.

Der ordo iudiciarius des Codex Bambergensis. Ed. Johann Friedrich Ritter von Schulte. Wien: Karl Gerold's Sohn, 1872.

Der ordo judiciaris 'Scientiam'. In: L. WAHRMUND. Quellen zur Geschichte des Römisch-Kanonischen Processes in Mittelalter: II. Band, I. Heft. Innsbruck: Wagnerischen K. K. Universitäts-Buchhandlung, 1913.

Ordonnace de Louis XIV Roy de France et de Navarre, donnée à Saint Germain en Laye au mois d'Avril 1667. Paris: Chez les Associez choisis par ordre de sa maiesté pour l'impression de ses nouvelles Ordonnances, 1667.

D’ORS, Alvaro (ed.). El Código de Eurico. 2.ed. Madrid: Boletín Oficial del Estado, 2014.

PABST, Haroldo. Natureza jurídica dos embargos do devedor. São Paulo: RT, 1986

PACHECO, José da Silva. Curso Teórico-Prático do Processo Civil: volume 1. Rio de Janeiro: Borsoi, 1956.

Evolução do Processo Civil Brasileiro: desde as origens até o advento do novo milênio. 2.ed. São Paulo: Renovar, 1999.

Tratado das execuções: volume 3, incidentes da execução. Rio de Janeiro: Borsoi, 1959.

PACÍFICO, Luiz Eduardo Boaventura. O ônus da prova. 2.ed. São Paulo: RT, 2011.

PAIVA, Ana Maria Alves de Oliveira e. Fernandes e Aurélio: um estudo comparativo de duas obras lexicográficas. Dissertação de Mestrado em Estudos em Linguística e Linguística Aplicada, Universidade Federal de Uberlândia, 2005.

PALAIA, Nelson. Técnica da contestação. São Paulo: Acadêmica, 1988.

PARIZATTO, João Roberto. Da contestação e da revelia: doutrina, jurisprudência, prática forense. Rio de Janeiro: Aide, 1991.

PARTOENS, Gert; Anthony DUPONT; Shari BOODTS (ed.). Praedicatio Patrum: studies on preaching in Late Antique North Africa. Turnhout: Brepols, 2017.

PASSOS, José Joaquim Calmon de: v. CALMON de PASSOS, José Joaquim

PAULA BAPTISTA, Francisco de. Compendio de theoria e pratica do processo civil. Recife: Typographia Universal, 1855. 
PAULSON, Stanley L.. Introduction. In: Stanley L. PAULSON; Bonnie Litschewski PAULSON. Normativity and Norms: critical perspectives on Kelsenian themes. Oxford: Clarendon Press, p. xxiii-liii.

PAVAN, Dorival Renato. Comentário ao art. 525. In: C. S. BUENO (coord.). Comentários ao Código de Processo Civil: volume 2, artigos 318 a 538, parte especial. São Paulo: Saraiva, 2017, p. 694-724.

PEGAS, Emmanuel Álvares. Commentaria ad Ordinationes Potentissimi Regni Portugalliae: tomus decimus quintus. Lisboa: Typis Patriarchalibus Francisci Ludovici Ameno, 1759.

. Resolutiones forenses practicabiles: pars secunda. Lisboa: Ex Typographia Michaelis Deslandes, 1682.

PENNER, Todd; Caroline Vander STICHELE. Rhetorical Practice and Performance in Early Christianity. In: Erik GUNDERSON (ed.). The Cambridge Companion to Ancient Rhetoric. Cambridge: Cambridge University Press, 2009, p. 245-60.

PEREIRA, Caio Mário da Silva. Anteprojeto de Código de Obrigações. Rio de Janeiro: Imprensa Nacional, 1964.

PEREIRA e SOUSA, Joaquim José Caetano. Primeiras Linhas sobre o Processo Civil: tomo I. Lisboa: Na Offic. de Joaquim Rodrigues d'Andrade, 1813.

. Primeiras Linhas sobre o Processo Civi accommodadas ao Fôro do Brasil até o anno de 1877 por Augusto Teixeira de Freitas: tomo 1. Rio de Janeiro: Typographia Perseverança, 1879.

PETERS, Egbert. Comentário ao §138. In: Gerhard LÜKE; Alfred WALCHSHÖFER. Münchener Kommentar zur Zivilprozessordnung: Band 1, §§ 1-354. München: Beck, 1992, p. 991-997.

PHILIP, James A.. Platonic diairesis. Transactions and Proceedings of the American Philological Association, n. 97, p. 335-58, 1966.

PIMENTA BUENO, José Antônio. Apontamentos sobre as Formalidades do Processo Civil. Rio de Janeiro: Typ. Imp. e Const. de J. Villeneuve e Comp., 1850.

PIMENTEL, Wellington Moreira. Comentários ao Código de Processo Civil: volume 3, artigos 270 a 331 e 444 a 475. São Paulo: RT, 1975.

PINELI, Arii. Ad Rubricam et L. II. C. de Rescindenda Venditione. Frakfurt: Ex officina Typographica Nicolai Bassaei, 1597.

PINHEIRO, Francisco Batista Marques. Jurisprudencia commercial: collecção de todas as sentenças proferidas em gráo de revista pelo Supremo Tribunal de Justiça e accordãos revisores dos Tribunnaes do Commercio. Rio de Janeiro: Typographia do Apostolo, 1870. 
PINHO, Humberto dalla Bernardina de. Direito Processual Civil Contemporâneo: volume 2. 5.ed. São Paulo: Saraiva, 2018.

PINTO, Carlos Alberto da Mota: v. MOTA PINTO, Carlos Alberto da

PINTO, José Maria Frederico de Souza: v. SOUZA PINTO, José Maria Frederico de

PINTO, Rui. Notas ao Código de Processo Civil. Coimbra: Coimbra, 2014.

PISANI, Andrea Proto. Lezioni di diritto processuale civile. 6.ed. Napoli: Jovene, 2014.

PISTILLI, Ana de Lourdes Coutinho Silva. Defesas do executado no cumprimento da sentença condenatória ao pagamento de quantia (Lei $\left.n^{0} 11.232 / 05\right)$ e na execução de títulos extrajudiciais (Lei $\left.n^{0} 11.382 / 06\right)$ - visão comparativa. In: Carlos Alberto CARMONA. Reflexões sobre a Reforma do Código de Processo Civil: estudos em homenagem a Ada Pellegrini Grinover, Cândido R. Dinamarco e Kazuo Watanabe. São Paulo: Atlas, 2007, p. 85-107.

PLÁCIDO e SILVA, Oscar Joseph de. Comentários ao Código de Processo Civil. Curitiba/São Paulo/Rio de Janeiro: Guaíra, 1940.

PLATON. Oeuvres complètes: tome III, $2^{\mathrm{e}}$ partie, Gorgias - Menon. Ed. e trad. Alfred Croiset. 2.ed. Paris: Les Belles Lettres, 1935.

. Oeuvres complètes: tome IV, $3^{\mathrm{e}}$ partie, Phèdre. Ed. e trad. Léon Robin. Paris: Les Belles Lettres, 1947.

. Oeuvres complètes: tome VIII, $2^{\mathrm{e}}$ partie, Théétète. Ed. e trad. Auguste Diès. Paris: Les Belles Lettres, 1965.

. Oeuvres complètes: tome VIII, $3^{\mathrm{e}}$ partie, Le Sophiste. Ed. e trad. Auguste Diès. Paris: Les Belles Lettres, 1963.

. Oeuvres complètes: tome IX, $1^{\text {re }}$ partie, Le Politique. Ed. e trad. Auguste Diès. Paris: Les Belles Lettres, 1960.

. Oeuvres complètes: tome IX, $2^{\mathrm{e}}$ partie, Philèbe. Ed. e trad. Auguste Diès. Paris: Les Belles Lettres, 1949.

PLINE LE JEUNE. Lettres: tome I ${ }^{\text {er }}$, livres I-III. 4.ed. Ed. e Trad. Anne-Marie Guillemin. Paris: Les Belles Lettres, 1961.

. Lettres: tome II, livres IV-VI. 2.ed. Ed. e Trad. Anne-Marie Guillemin. Paris: Les Belles Lettres, 1962.

Lettres: tome III, livres VII-IX. 2.ed. Ed. e Trad. Anne-Marie Guillemin. Paris: Les Belles Lettres, 1959.

POHLE, Rudolf. Rezension. Archiv für die civilistische Praxis, n. 155 (2), p. 165-80, 1956.

POMIAN, Krzysztof. L'Ordre du Temps. Paris: Gallimard, 1984. 
PONTES DE MIRANDA, Francisco Cavalcanti. Comentários ao Código de Processo Civil: volume 1, artigos $1^{\circ}$ a 152. Rio de Janeiro: Forense, 1947.

. Comentários ao Código de Processo Civil: volume 1, artigos $1^{\circ}$ a 45 . Rio de Janeiro: Forense, 1974.

. Comentários ao Código de Processo Civil: tomo 3, artigos 161 a 272. Rio de Janeiro: Forense, 1958.

. Comentários ao Código de Processo Civil: tomo 4, artigos 282 a 443. Rio de Janeiro: Forense, 1974.

. Comentários ao Código de Processo Civil: tomo 13, artigos 890 a 981 . Rio de Janeiro: Forense, 1977.

Parecer n. 52. In: . Dez Anos de Pareceres: volume 3. Rio de Janeiro: Francisco Alves, 1974, p. 46-49.

Parecer n. 280. In: . Dez Anos de Pareceres: volume 10. Rio de Janeiro: Francisco Alves, 1977, p. 378-95.

. Tratado das ações: tomo 2, ações declarativas. São Paulo: RT, 1971.

. Tratado das ações: tomo 5, ações condenatórias. São Paulo: RT, 1974.

. Tratado de Direito Privado: tomo 1, parte geral, introdução, pessoas físicas e jurídicas. São Paulo: RT, 2012.

. Tratado de Direito Privado: tomo 4, parte geral, validade, nulidade, anulabilidade. São Paulo: RT, 2012.

- Tratado de Direito Privado: tomo 5, parte geral, eficácia jurídica, determinações inexas e anexas, direitos, pretensões, ações. São Paulo: RT, 2012.

PUOLI, José Carlos Baptista. Comentário ao artigo 550. In: Cassio Scarpinella BUENO. Comentários ao Código de Processo Civil: volume 3, artigos 539 a 925, parte especial. São Paulo: Saraiva, 2017, p. 32-38.

. Comentário ao art. 704. In: Cassio Scarpinella BUENO. Comentários ao Código de Processo Civil: volume 3, artigos 539 a 925, parte especial. São Paulo: Saraiva, 2017, p. 360.

[QUINTILIAN.] The Lesser Declamations: volume 1. Ed. e Trad. D. R. Shackleton Bailey. Cambridge, Ma/London: Harvard University Press, 2006.

QUINTILIEN. Institution Oratoire: tomo II, livres II et III. Ed. e Trad. Jean Cousin. Paris: Les Belles Lettres, 1976.

QUINTILIEN. Institution Oratoire: tome III, livres IV et V. Ed. e Trad. Jean Cousin. Paris: Les Belles Lettres, 1976. 
QUINTILIEN. Institution Oratoire: tome IV, livres VI et VII. Ed. e Trad. Jean Cousin. Paris: Les Belles Lettres, 1977.

RADCLIFFE-BROWN, Alfred Reginald. Social sanctions. In: Structure and Function in Primitive Society. London: The Free Press, 1965, p. 205-11.

RADIN, Max. A Restatement of Hohfeld. Harvard Law Review, Cambridge, n. 51 (7), p. 1141-64, 1938.

RAMALHO, Joaquim Ignacio. Postillas de Pratica: collecção completa das licções de Pratica do anno de 1865, precedidas de cinco licções de Hemeneutica Jurídica e seguidas de dez de Processo Criminal, inteiramente correctas. 2.ed. São Paulo: Typographia Americana, 1872.

. Practica civil e commercial. São Paulo: Typographia Imparcial de Joaquim Roberto de Azevedo Marques, 1861.

Praxe Brasileira. São Paulo: Typographia do Ypiranga, 1869.

RAMOS, Joaquim José Pereira da Silva. Manual Pratico do Processo Commercial: tomo I. 2.ed. Rio de Janeiro: Eduardo \& Henrique Laemmert, 1864.

RAMOS, Vitor de Paula. Ônus e deveres probatórios das partes no Novo CPC brasileiro. In: L. B. de MACEDO; R. PEIXOTO; A. FREIRE (org.). Provas. 2.ed. Salvador: Juspodivm, 2016, p. 263-82. (Coleção Novo CPC: doutrina selecionada, coordenada por Fredie Didier Jr., volume 3).

Ônus da prova no processo civil: do ônus ao dever de provar. São Paulo: RT, 2015 (Coleção O novo processo civil, dirigida por Luiz Guilherme MARINONI).

REIS, José Alberto dos: v. ALBERTO dos REIS, José

Remains of Old Latin: III, Lucilius, Laws of the Twelve Tables. Ed. e Trad. E. H. Warmington. London/ Cambridge, Ma: William Heinemann/Harvard University Press, 1941 (Coleção The Loeb Classical Library, volume 329, editada por L. A. Post e E. H. Warmington).

RENDON, José Arouche de Toledo. Elementos de Processo Civil, precedidos de instruções para os juízes municipais. São Paulo: Typographia do Governo, 1850.

REZENDE FILHO, Gabriel. Curso de Direito Processual Civil: volume 2. 4.ed. São Paulo: Saraiva, 1955.

van RHEE, Cornelis Hendrik. The Influence of the French Code de Procédure Civile (1806) in 19th Century Europe. In: Loïc CADIET; Guy CANIVET (coord.). 1806 - 1976 - 2006 - De la commémoration d'un code à l'autre: 200 ans de procédure civile en France. Paris: Litec 2006, p. 129-65.

. Introduction. In:

(ed.). European Traditions in Civil Procedure. Antwerpen/Oxford: Intersentia, 2005, p. 3-23. 
Die Rhetorica Ecclesiastica. In: L. WAHRMUND. Quellen zur Geschichte des RömischKanonischen Processes in Mittelalter: I. Band, IV. Heft. Innsbruck: Verlag der Wagner'schen Universitäts-Buchhandlung, 1906.

Rhétorique à Hérennius. Ed. e Trad. Henri Bornecque. Paris: Librairie Garnier Frères, 1932.

RIBEIRO, Armando Vidal Leite. Consolidação das Disposições Referentes ao Processo Civil e Commercial da Justiça Local do Districto Federal: vigentes em 31 de julho de 1913. Rio de Janeiro: Graphicas da S.A. Progresso, 1913.

RIBEIRO, Darci Guimarães. Comentário ao art. $7^{\circ}$. In: C. S. BUENO (coord.). Comentários ao Código de Processo Civil: volume 1, artigos $1^{\circ}$ a 317 - parte geral. São Paulo: Saraiva, 2017, p. 109-15.

RIBEIRO [dos SANTOS], Jacinto. Dos Libellos (Tratado da Forma dos Libellos do licenciado Gregorio Martins Caminha): tirada da edição de 1731 e annotada de accôrdo com a legislação vigente. Rio de Janeiro: Jacintho Ribeiro dos Santos, 1919.

RIBEIRO, Jozé Pinto. Memória sobre o assumpto proposto pela Academia Real das Sciencias de Lisboa no anno de 1791, qual seja a época da introducção do Direito das Decretaes em Portugal, e o influxo que o mesmo teve na Legislação Portugueza. In: Memorias de Litteratura Portugueza Publicadas pela Academia Real das Sciencias de Lisboa: tomo VI. Lisboa: Na Typographia da Mesma Academia, 1796, p. 5-34.

RICHTER, Emil Ludwig (ed.). Corpus Iuris Canonici: pars prior, Decretum Magistri Gratiani. Leipzig: Bernhard Tauchnitz, 1922.

(ed.). Corpus Iuris Canonici: pars secunda, Decretalium Collectiones. Leipzig: Bernhard Tauchnitz, 1922.

RICOEUR, Paul. Événement et sens. In: L'espace et le temps: actes du XXII congrès de l'association des sociétés de langue française, Dijon 1988, problèmes et controverses. Paris/Dijon: Vrin/Société Bourguignonne de Philosophie, 1991, p. 9-21.

La mémoire, l'histoire, l'oubli. Paris: Seuil, 2000.

ROCHA, Felippe Borring. Manual dos Juizados Especiais Cíveis e Federais: teoria e prática. 9.ed. São Paulo: Atlas, 2017.

RODRIGUES, Fernando Pereira. Noções Fundamentais de Processo Civil. Coimbra: Almedina, 2015.

ROQUE, Andre Vasconcelos. A estabilização da demanda no novo CPC: uma oportunidade perdida? In: Lucas Buril de MACEDO; Ravi PEIXOTO; Alexandre FREIRE (org.). Procedimento Comum. 2.ed. Salvador: Juspodivm, 2016, p. 299-331 (Coleção Novo CPC: doutrina selecionada, coordenada por Fredie Didier Jr., volume $2)$. 
ROSA, Innocencio Borges da: v. BORGES da ROSA, Innocencio

ROSENBERG, Leo. Der Beweislast auf der Grundlage des Bürgerlichen Gesetzbuchs und der Zivilprozeßordnung. 3.ed. München: C.H. Beck, 1953.

; Karl Heinz SCHWAB; Peter GOTTWALD. Zivilprozessrecht. 17.ed. München: C.H. Beck, 2010.

ROSS, Alf. Directives and Norms. London/New York: Routledge \& Kegan Paul/Humanities Press, 1968.

ROVER, Tadeu. Legislador não pode restringir conceito de fundamentação, diz Anamatra. Conjur, 9 mar. 2015. Disponível em: <https://www.conjur.com.br/2015-mar09/legislador-nao-restringir-conceito-fundamentacao-anamatra> Acesso em: 24 set. 2018.

SÁ, Fernando Augusto Cunha de. Abuso do Direito. Lisboa: Ministério das Finanças, 1973.

SALLUSTE. Catilina - Jugurtha - Fragments des Histoires. 5.ed. Ed. e Trad. Alfred Ernout. Paris: Les Belles Lettres, 1962.

SANT'AGOSTINO. La dottrina cristiana. Ed. e Trad. Vincenzo Tarulli. Roma: Città Nuova, 1992.

SANTOS, Gildo dos. Locação e despejo: comentários à Lei 8.245/91. 3.ed. São Paulo: RT, 1999.

SANTOS, Moacyr Amaral: v. AMARAL SANTOS, Moacyr

SATTA, Salvatore. Diritto Processuale Civile. 7.ed. Padova: CEDAM, 1967.

SAUSSURE, Ferdinand de. Curso de linguística geral. 28.ed. Trad. Antônio Chelini, José Paulo Paes, Izidoro Blikstein. São Paulo: Cultrix, 2012.

von SAVIGNY, Friedrich Carl. Storia del Diritto Romano nel Medio Evo: volume 2. Trad. Emmanuele Bollati. Torino: Gianni e Fiori, 1854-57.

. System des heutigen Römischen Rechts: dritter Band. Berlin: Veit und Comp., 1840 .

SCAVONE JUNIOR, Luiz Antônio. Modelos de peças no novo CPC. Rio de Janeiro: Forense, 2015.

SCHIAVONE, Aldo. Linee di storia del pensiero giuridico romano. Torino: G. Giappichelli, 1994.

SCHLAG, Pierre. How to Do Things with Hohfeld. Law and Contemporary Problems, Durham, n. 78 (1-2), p. 185-234, 2015. 
SCHMIDT, Jan Peter. Vida e obra de Pontes de Miranda a partir de uma perspectiva alemã: com especial referência à tricotomia 'existência, validade e eficácia do negócio jurídico’. Revista Fórum de Direito Civil, Belo Horizonte, n. 3, p. 135-58, jan./abr. 2014.

SCHMITZ, Leonard Ziesemer. Fundamentação das decisões judiciais: a crise na construção de respostas no processo civil. São Paulo: RT, 2015.

SCIALOJA, Vittorio. Procedimiento civil romano: ejercicio y defensa de los derechos. Trad. Santiago Sentis Melendo e Marino Ayerra Redin. Buenos Aires: EJEA, 1954.

SCOGNAMIGLIO, Renato. Fattispecie. In: Enciclopedia Giuridica: volume 15. Roma: Istituto della Enciclopedia Italiana, 2007, p. 1-8.

Fatto giuridico e fattispecie complessa. Rivista trimestrale di diritto e procedura civile, Milano, n. 8, p. 331-54, 1954.

SCOZZAFAVA, Oberdan Tommaso. Onere (in generale): a) nozione. In: Costantino MORTATI; Francesco SANTORO-PASSARELLI (coord.). Enciclopedia del Diritto: volume 30, omissione-ordine. Milano: Giuffrè, 1980, p. 99-113.

SECKEL, Emil. Distinctiones glossatorum. Graz: Akademische Druck- u. Verlagsanstalt, 1956.

SÉNÈQUE LE RHÉTEUR. Controverses et suasoires: tome premier. Ed. e Trad. Henri Bornecque. Paris: Garnier Frères, 1902.

SÉNÈQUE LE RHÉTEUR. Controverses et suasoires : tome deuxième. Ed. e Trad. Henri Bornecque. Paris: Garnier Frères, 1902.

SHERWIN-WHITE, Adrian Nicholas. The Letters of Pliny: a historical and social commentary. Oxford: The Clarendon Press, 1966.

SICA, Heitor Vitor Mendonça. Cognição do juiz na execução civil. São Paulo: RT, 2017. Comentário ao art. 341. In: Teresa Arruda Alvim WAMBIER (coord). Breves Comentários ao Novo Código de Processo Civil. São Paulo: RT, 2015, p. 915920.

. Comentário ao art. 341. In: Cassio Scarpinella BUENO (coord.). Comentários ao Código de Processo Civil: volume 2. São Paulo: Saraiva, 2017, p. 116-22.

. O direito de defesa no processo civil brasileiro: um estudo sobre a posição do réu. São Paulo: Atlas, 2011.

. Preclusão processual civil. 2.ed. São Paulo: Atlas, 2008.

. Preclusão processual civil nos Juizados Especiais. Revista do Advogado, São Paulo, n. 127, p. 59-66, ago. 2015. 
Reflexões em torno da teoria geral dos procedimentos especiais. Revista de Processo, São Paulo, n. 208, p. 61-89, jun. 2012.

- Velhos e novos institutos fundamentais do direito processual civil. In: Camilo ZUFELATO; Flávio Luiz YARSHELL (org.). 40 anos da Teoria Geral do Processo no Brasil. São Paulo: Malheiros, 2013, p. 430-66.

Las Siete Partidas del Sabio Rey Don Alonso el Nono, glosadas por el licenciado Gregorio Lopez, del Consejo Real de Indias de S. M.: tomo II, que contiene la III ${ }^{\mathrm{a}}, \mathrm{IV}^{\mathrm{a}}$ y V $V^{\mathrm{a}}$ partida. Madrid: En la Oficina de Benito Cano, 1789.

SILVA, Blecaute de Oliveira. Contornos da fundamentação no Novo CPC. In: Lucas Buril de MACEDO; Ravi PEIXOTO; Alexandre FREIRE (org.). Procedimento Comum. 2.ed. Salvador: Juspodivm, 2016, p. 447-61 (Coleção Novo CPC: doutrina selecionada, volume 2, coordenada por Fredie DIDIER JR).

SILVA, Clóvis. V. do Couto e: v. COUTO e SILVA, Clóvis V.

SILVA, Homero Batista Mateus da. Curso de Direito do Trabalho Aplicado: volume 9, processo do trabalho. 2.ed. São Paulo: RT, 2015.

SILVA, Innocencio Francisco da. Diccionario Bibliographico Portuguez: tomo primeiro. Lisboa: Imprensa Nacional, 1858.

. Diccionario Bibliographico Portuguez: tomo terceiro. Lisboa: Imprensa Nacional, 1859.

. Diccionario Bibliographico Portuguez: tomo quarto. Lisboa: Imprensa Nacional, 1860.

. Diccionario Bibliographico Portuguez: tomo quinto. Lisboa: Imprensa Nacional, 1860 .

. Diccionario Bibliographico Portuguez: tomo sexto. Lisboa: Imprensa Nacional, 1862.

SILVA, José Veríssimo Álvares da. Introducção ao novo Código, ou dissertação crítica sobre a principal causa da obscuridade do nosso codigo authentico. Lisboa: Regia Officina Typografica, 1780.

_. Memoria sobre a fórma dos Juizos nos primeiros Seculos da Monarquia Portugueza. In: Memorias de Litteratura Portugueza Publicadas pela Academia Real das Sciencias de Lisboa: tomo VI. Lisboa: Na Typographia da Mesma Academia, 1796, p. 35-100.

SILVA, Juno J. Espinosa Gomes da: v. GOMES da SILVA, Nuno J. Espinosa

SILVA, Manuel Dias da. Processos civis especiaes. 2.ed. revista e atualizada por José Alberto dos Reis. Coimbra: F. França Amado, 1919.

SILVA, Oscar Joseph de Plácido e: v. PLÁCIDO e SILVA, Oscar Joseph de 
SILVA, Ovídio Baptista da: v. BAPTISTA da SILVA, Ovídio Araújo

SILVA, Paula Costa e. O processo e as situações jurídicas processuais. In: Fredie DIDIER JR; Eduardo JORDÃO (coord.). Teoria do processo: panorama doutrinário mundial. Salvador: Juspodivm, 2008, p. 769-808.

SILVA, Ricardo Alexandre da; Eduardo LAMY. Comentários ao Código de Processo Civil: volume 9, artigos 539 ao 673. São Paulo: RT, 2016 (Coleção Comentários ao Código de Processo Civil, dirigida por Luiz Guilherme Marinoni e coordenada por Sérgio Cruz Arenhart e Daniel Mitidiero).

SIMPSON, Adelaide Douglas. A Christian Argument Against Rhetoric. The Classical Weekly, Baltimore, n. 32 (20), p. 232-33, 1943.

SIQUEIRA, A. do Valle. Das acções summarias: doutrina e pratica. São Paulo: Saraiva, 1922. . Inventarios e partilhas. São Paulo: Saraiva, 1922.

SMITH, Robin. Logic. In: Jonathan BARNES (ed.). The Cambridge Companion to Aristotle. Cambridge: Cambridge University Press, 1995, p. 27-65.

SOUSA, Joaquim José Caetano Pereira e: v. PEREIRA e SOUSA, Joaquim José Caetano

SOUSA, Miguel Teixeira de: v. TEIXEIRA de SOUSA, Miguel

SOUZA, José Barcelos de. Teoria e prática da ação de execução fiscal e dos embargos do executado. São Paulo: Saraiva, 1986.

SOUZA PINTO, José Maria Frederico de. Primeiras Linhas sobre o Processo Civil Brasileiro: tomo 2. Rio de Janeiro: Eduardo e Henrique Laemmert, 1850.

STEEL, Catherine. Roman Oratory. Cambridge: Cambridge University Press, 2006.

STEINWENTER, Artur. Die Litiskontestation im Libellprozesse. Zeitschrift der SavignyStiftung für Rechtsgeschichte: Romanistische Abtheilung, Wien, n. 50 (1), p. 184211, 1930.

STRECK, Lênio Luiz. Comentário ao artigo 489. In: Lênio Luiz STRECK; Dierle NUNES; Leonardo Carneiro da CUNHA (org.). Comentários ao Código de Processo Civil. São Paulo: Saraiva, 2016, p. 681-92.

STROUP, Sarah Culpepper. Greek Rhetoric Meets Rome: expansion, resistance, acculturation. In: William DOMINIK; Jon HALL (ed.). A Companion to Roman Rhetoric. Oxford: Blackwell, 2007, p. 23-37.

SUÉTONE. Vies des Douze Césars: tome 2, Tibère, Caligula, Claude, Néron. Ed. e trad. Henri Ailloud. Paris: Les Belles Lettres, 1957.

Die Summa Aurea des Wilhelmus de Drokeda. In: L. WAHRMUND. Quellen zur Geschichte des Römisch-Kanonischen Processes in Mittelalter: II. Band, II. Heft, Innsbruck: Verlag der Wagner'schen Universitäts-Buchhandlung, 1914. 
Die Summa Minorum des Magister Arnulphus. In: L. WAHRMUND. Quellen zur Geschichte des Römisch-Kanonischen Processes in Mittelalter: I. Band, II. Heft, II, 2, XII, Innsbruck: Verlag der Wagner'schen Universitäts-Buchhandlung, 1905.

SYLVA, Emmanuel Gonçalves da. Commentaria ad Ordinationes Regni Portugalliae: tomus primus. Lisboa: Ex Typographia Augustiniana, 1731.

. Commentaria ad Ordinationes Regni Portugalliae: tomus secundus. Lisboa: Ex Typographia Antonii Pedrozo Galram, 1732.

TABOSA, Fábio. Comentário ao artigo 340. In: A. C. MARCATO (coord.). Código de Processo Civil Interpretado. 3.ed. São Paulo: Atlas, 2008, p. 1084-1806.

TALAMINI, Eduardo. Comentário ao art. 357. In: BUENO (coord). Comentários ao Código de Processo Civil: volume 1, artigos $1^{\circ}$ a 317 - parte geral. São Paulo: Saraiva, 2017, p. 182-214.

Tutela monitória: a ação monitória - lei 9.089/95. São Paulo: RT, 1998.

Tancredi Bononiensis ordo iudiciarius. In Pillii, Tancredi, Gratiae libri de iudiciorum ordine. Ed. Friedrich Bergmann. Göttingen: Vandenhoeck et Ruprecht, 1842, p. 87-314.

TARDIF, Adolphe. La procédure civile et criminelle aux XIII et XIV siècles, ou procédure de transition. Paris: Alphonse Picard/L. Larose \& Focel, 1885.

TARDIF, Ernest Joseph. Coutumiers de Normandie: première partie, le très ancien coutumier de Normandie. Rouen: Imprimerie de Espérance Gagniard, 1881.

TARTUCE, Fernanda. Igualdade e vulnerabilidade no processo civil. Rio de Janeiro: Forense, 2012.

Reflexões sobre a atuação de litigantes vulneráveis sem advogado nos Juizados Especiais Cíveis. Revista do Advogado, São Paulo, n. 127, p. 47-57, ago. 2015.

TARTUCE, Fernanda; Luiz DELLORE. Manual de prática civil. 12.ed. São Paulo: Método, 2016.

TARUFFO, Michele. Aspectos fundamentais do processo civil de civil law e de common law. In: M. TARUFFO. Processo Civil Comparado: ensaios. Trad. Daniel Mitidiero. São Paulo: Marcial Pons, 2013, p. 11-34.

- A motivação da sentença civil. Trad. Daniel Mitidiero, Rafael Abreu e Vitor de Paula Ramos. São Paulo: Marcial Pons, 2015.

A prova. Trad. João Gabriel Couto. São Paulo: Marcial Pons, 2014.

Rethinking the standards of proof. The American Journal of Comparative Law, $\mathrm{n}$. 51, p. 659-77, 2003.

. Uma simples verdade: o juiz e a construção dos fatos. São Paulo: Marcial Pons, 2016. 
; Daniel MITIDIERO. A Justiça Civil: da Itália ao Brasil, dos Setecentos a hoje. São Paulo: RT, 2018.

TEIXEIRA, Sálvio de Figueiredo. Inovações e Estudos do Código de Processo Civil. São Paulo: Saraiva, 1976.

TEIXEIRA FILHO, Manoel Antonio. Petição inicial e resposta do réu. São Paulo: LTr, 1996.

TEIXEIRA de FREITAS, Augusto. Consolidação das leis civis. 3.ed. Rio de Janeiro: H. Garnier, 1896.

TEIXEIRA de SOUSA, Miguel. Algumas questões sobre o ónus de alegação e de impugnação no novo processo civil português. Revista de Processo, n. 228, p. 311-324, fev. 2014

THEODORO JÚNIOR, Humberto. Curso de Direito Processual: volume 1, teoria geral do direito processual civil, processo de conhecimento, procedimento comum. 56.ed. Rio de Janeiro: Forense, 2015.

. Curso de Direito Processual Civil: volume 2, procedimentos especiais. 50.ed. Rio de Janeiro. Forense, 2016.

. Curso de Direito Processual Civil: volume 3, execução forçada, processo nos tribunais, recursos, direito intertemporal. 47.ed. Rio de Janeiro: Forense, 2016.

. Estabilização da demanda no Novo Código de Processo Civil. Revista de Processo, São Paulo, n. 244, p. 195-204, jun. 2015.

A execução de sentença e a garantia do devido processo legal. Rio de Janeiro: Aide, 1987.

Relatório Brasileiro - Abuso de Direito Processual no Ordenamento Jurídico Brasileiro. In: José Carlos BARBOSA MOREIRA (coord.). Abuso dos Direitos Processuais. Rio de Janeiro: Forense, 2000, p. 93-129.

THEODORO JÚNIOR, Humberto, et alii. Novo CPC: fundamentos e sistematização. 2.ed. Rio de Janeiro: Forense, 2015.

TOMASETTI JR., Alcides. Perecimento do direito de domínio e improcedência da ação reivindicatória. Favela consolidada sobre terreno urbano loteado. Função social da propriedade. Prevalência da Constituição Federal sobre o direito comum. Revista dos Tribunais (São Paulo), n. 723, p. 204-23, 1996.

TORNAGHI, Helio. Comentários ao Código de Processo Civil: volume 2, artigos 154 a 269. São Paulo: RT, 1975.

TORRENTE, Andrea; Piero SCHLESINGER. Manuale di Diritto Privato. 23.ed. Ed. Franco Anelli e Carlo Granelli. Milano: Giuffrè, 2017.

TUCCI, José Rogério Crus e: v. CRUZ e TUCCI, José Rogério 
TUCCI, Rogério Lauria. Curso de Direito Processual Civil: volume 2, processo de conhecimento, processo e respectivos procedimentos. São Paulo: Saraiva, 1989.

Manual do Juizado Especial de Pequenas Causas: anotações à Lei n. 7.244, de 711-1984. São Paulo: Saraiva, 1985.

Temas e Problemas de Direito Processual. São Paulo: Saraiva, 1984.

TUPINAMBÁ, Hermes. A contestação no processo trabalhista. Belém: CEJUP. 1983.

VANGUERVE CABRAL, Antonio. Pratica Judicial: prymeira parte. Lisboa: Officina de Joseph Lopes Ferreyra, 1712.

VARELA, João de Matos Antunes: v. ANTUNES VARELA, João de Matos

VELloso, Antonio Augusto. Manual do Processo Civil: elementos de theoria e pratica e formularios das acções, incidentes do processo e processos complementares. Belo Horizonte: Imprensa Official do Estado de Minas Geraes, 1912.

VERDE, Giovanni. L'onere della prova nel processo civile. Napoli: Jovene, 1974.

VERGARA, Osvaldo. Código do Processo Civil e Comercial do Estado do Rio Grande do Sul: Lei n. 56 de 16 de janeiro de 1908, com a jurisprudência do Superior Tribunal do Estado até 1931, com inúmeros comentários de doutrina e com as modificações introduzidas pelo Código Civil Brasileiro. 3.ed. Porto Alegre: Livraria do Globo, 1936.

VICENTE, Fabrizio Matteucci. A natureza jurídica da impugnação da nova execução. In: Susana Henriques da COSTA (org.). A Nova Execução Civil: Lei 11.232/05. São Paulo: Quartier Latin, 2006, p. 217-31.

de VITA, Fabrizio. Onere di contestazione e modelli processuali. Roma: Dike, 2012.

WACH, Adolf. Das Geständniß: ein Beitrag zur Lehre von den processualistischen Rechtsgeschäften. Archiv für die civilistische Praxis, Tübingen, n. 64, p. 201-55, 1881.

. Vorträge über die Reichs-Civilprocessordnung. 2.ed. Bonn: Adolph Marcus, 1896.

WALDE, Alois; Johann Baptist HOFFMAN, Lateinisches etymologisches Wörterbuch: zweiter Band. 3.ed. Heidelberg: Carl Winter, 1954.

WAMBIER, Luiz Rodrigues; Eduardo TALAMINI. Curso Avançado de Processo Civi: volume 2, cognição jurisdicional, processo comum de conhecimento e tutela provisória. 16.ed. São Paulo: RT, 2016.

RT, 2017.

. Curso Avançado de Processo Civil: volume 3, execução. 16.ed. São Paulo: 
WAMBIER, Tereza Arruda Alvim. Comentário ao artigo 489. In: Cassio Scarpinella BUENO (coord.). Comentários ao Código de Processo Civil: volume 2. São Paulo: Saraiva, 2017, p. 43038.

WAMBIER, Tereza Arruda Alvim, et alii. Primeiros Comentários ao Novo Código de Processo Civil: artigo por artigo. São Paulo: RT, 2015.

WARD, John O. Roman Rhetoric and Its Afterlife. In: William DOMINIK; Jon HALL (ed.). A Companion to Roman Rhetoric. Oxford: Blackwell, 2007, p. 354-66.

WATANABE, Kazuo. Da cognição no processo civil. 2.ed. Campinas: Bookseller, 2000.

WENGER, Leopold. Institutes of the Roman Law of Civil Procedure. Trad. Otis Harrison Fisk. New York: Veritas, 1940.

WETZELL, Georg Wilhelm. System des ordentlichen Civilprocesses. 2.ed. Leipzig: Bernhard Tauschnitz, 1865.

WICKHAM, Chris. Framing the Early Middle Ages: Europe and the Mediterranean, 400800. Oxford: Oxford University Press, 2005.

WILKINSON, Alexander S. (ed.). Iberian Books: books published in Spanish or Portuguese or on the Iberian Peninsula before 1601. Leiden/Boston: Brill, 2010.

WINDSCHEID, Bernhard. Lehrbuch des Pandektenrechts: erster Band. 5.ed. Frabkfurt am Main: Kütten \& Loening, 1882.

WOLF, Manfred; Jörg NEUNER. Allgemeiner Teil des Bürgerlichen Rechts. 10.ed. München: Beck, 2012.

WORMAN, Nancy. Fighting words: status, stature and verbal contest in archaic poetry. In: Erik GUNDERSON (ed.). The Cambridge Companion to Ancient Rhetoric. Cambridge: Cambridge University Press, 2009, p. 27-42.

WRIGHT, Georg Henrik von. Deontic Logic. Mind, Oxford, n. 60, p. 1-15, 1951.

YARSHELL, Flávio Luiz. Ação rescisória: juízos rescindente e rescisório. São Paulo: Malheiros, 2005.

Antecipação da prova sem o requisito da urgência e direito autônomo à prova. São Paulo: Malheiros, 2009.

. Curso de Direito Processual Civil: volume 1. São Paulo: Marcial Pons, 2014.

. Tutela jurisdicional específica nas obrigações de declaração de vontade. São Paulo: Malheiros, 1993.

; Guilherme Setoguti J. PEREIRA; Viviane Siqueira RODRIGUES. Comentários ao Código de Processo Civil: volume 5, artigos 334 ao 368. São Paulo: RT, 2016, p. 165-166 (Coleção Comentários ao Código de Processo Civil, dirigida por Luiz Guilherme e coordenada por Sergio Cruz ARENHART e Daniel MITIDIERO). 
ZASIUS, Ulrich. In titulo institutionum de actionibus enarratio. Basel: Apud Mich. Isingrinium, 1537. 